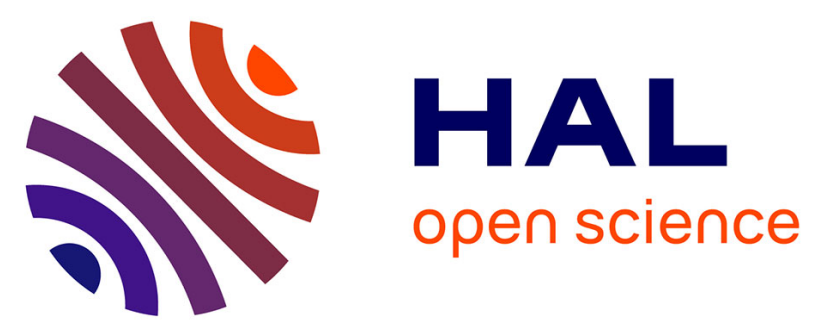

\title{
Time, place and mode of propagation of foreland basin systems as recorded by the sedimentary fill: examples of the Late Cretaceous and Eocene retro-foreland basins of the north-eastern Pyrenees
}

Frédéric Christophoul, Jean-Claude Soula, Stéphane Brusset, Brice Elibana, Martin Roddaz, Gilbert Bessière, Joachim Déramond

\section{To cite this version:}

Frédéric Christophoul, Jean-Claude Soula, Stéphane Brusset, Brice Elibana, Martin Roddaz, et al.. Time, place and mode of propagation of foreland basin systems as recorded by the sedimentary fill: examples of the Late Cretaceous and Eocene retro-foreland basins of the north-eastern Pyrenees. Special Publication - Geological Society of London, 2003, 208, pp.229-252. 10.1144/GSL.SP.2003.208.01.11 . hal-00672004

\author{
HAL Id: hal-00672004 \\ https://hal.science/hal-00672004
}

Submitted on 23 Feb 2012

HAL is a multi-disciplinary open access archive for the deposit and dissemination of scientific research documents, whether they are published or not. The documents may come from teaching and research institutions in France or abroad, or from public or private research centers.
L'archive ouverte pluridisciplinaire HAL, est destinée au dépôt et à la diffusion de documents scientifiques de niveau recherche, publiés ou non, émanant des établissements d'enseignement et de recherche français ou étrangers, des laboratoires publics ou privés. 


\title{
Time, place and mode of propagation of foreland basin systems as recorded by the sedimentary fill: examples of the Late Cretaceous and Eocene retro-foreland basins of the north-eastern Pyrenees
}

\author{
F. CHRISTOPHOUL, J.-C. SOULA, S. BRUSSET, B. ELIBANA, M. RODDAZ, G. \\ BESSIERE \& J. DERAMOND
}

\author{
Laboratoire des Mécanismes de Transferts en Géologie, UMR 5563, \\ Université Paul Sabatier, 38 rue des 36 ponts, 31400 Toulouse, France \\ (e-mail: christop@cict.fr)
}

\begin{abstract}
The relationship between tectonics and sedimentary fill has been studied in two syncontractional basins of the western Corbières (eastern North Pyrenean retro-foreland basin). The Late Cretaceous basin formed during $c .10-12 \mathrm{Ma}$ as a result of left-lateral transpressional deformation, and is composed of forward-younging sub-basins characterized by reworking of the forelimbs of growing fold-propagation folds. Thrust-wedge advance and cratonward migration of the platform are recorded by a deepening-upward stacking pattern indicating increased regional subsidence with a limited contribution of the submarine orogen. Tectonic quiescence and erosional unloading lasting 29-30 Ma are recorded by a shallowingupward stacking pattern, and fluvial sedimentation issued from widespread sources in the emerging inner orogen. The Early to Middle Eocene basin formed as a result of pure shortening normal to the range. The marine Early Eocene basin developed during $c .2 \mathrm{Ma}$ by widening of a single basin provoked by the two-step propagation of a basement duplex. This is recorded by growth-stratal patterns and coarsening-upward depositional sequences indicating the increasing contribution of the emerged orogen. The Middle Eocene continental deposits infilled two sub-basins working synchronously and were transported by alluvial fans with a provenance in the inner orogen, during decreasing thrust-wedge advance and increasing erosional unloading.
\end{abstract}

Foreland basins have long been favoured as areas for tracing orogenic events using the sedimentary record. The propagation of a foreland basin is achieved by either the development of forwardyounging distinct fault thrust-related subbasins progressively integrated into the wedge (Déramond et al. 1993; DeCelles \& Giles 1996; Horton \& DeCelles 2001), or forward migration and/or deepening/widening of a single basin (Catuneanu et al. 1997, 2000; Sinclair 1997; Burkhard \& Sommaruga 1998; Christophoul et al. 2002).

At the regional scale, deposition in foreland basins is widely controlled by flexural subsidence resulting from tectonic and sublithospheric static and dynamic loading (Beaumont 1981; Beaumont et al. 1993; Washbusch et al. 1996, Catuneanu et al. 1997, 2000). Tectonic loading is frequently considered to be followed by tectonic quiescence/ unloading resulting from release of lithospheric forces and/or erosion (e.g. Blair and Bilodeau
1988; Heller et al. 1988; Heller \& Paola 1992, Burbank 1992; Catuneanu et al. 1997, 2000), which implies that loading/unloading cycles are related to the major tectonic events. Catuneanu et al. $(1997,2000)$ have, however, described a succession of basin-scale loading/unloading cycles controlling second- and third-order sedimentary sequences with time-spans of c. $20-25$ and 0.4 to $3 \mathrm{Ma}$.

The question of the transition from underfilled to overfilled is closely related to foreland basin propagation and loading/unloading cycles. Most frequently, this is intended as the transition from marine to non-marine deposition, when the volume of sediment delivered from the orogen becomes greater than accommodation space (e.g. Ricci Lucchi 1986; DeCelles and Giles 1996; Sinclair 1997). According to Jordan (1995), the transition from underfilled to overfilled marks the change from a subsiding foredeep parallel and close to the wedge front to a large-scale 
transverse sediment transport widely outpacing the former foredeep. In spite of differing definitions, both Sinclair (1997) and Jordan (1995) invoke an increase in tectonic shortening. In contrast, other authors (Blair and Bilodeau 1988; Heller et al. 1988; Heller \& Paola 1992; Burbank 1992) believe that the transition from longitudinal to transverse drainage is due to erosional unloading succeeding tectonic loading.

How are these events recorded in the sedimentary fill? Tectonism is often emphasized as a forcing mechanism of depositional sequences in active basins (e.g. Clifton et al. 1988; Carter et al. 1991; Vail et al. 1991; Sinclair 1993; Yoshida et al. 1996; Catuneanu et al. 1997, 2000; Serrano et al. 2001), even though attempts to relate sequence stratigraphy to thrust/fold sequence are rather few in number (Specht 1989; WallezFondecave \& Souquet 1991; Déramond et al. 1993; Brusset et al. 1997; Ito et al. 1999). Traces of tectonic events, however, are likely to have been recorded by other sedimentary features, including facies, provenance, and palaeocurrents (e.g. Sinclair 1992, 1997; Schlunegger et al. 1997a, b; DeCelles et al. 1998; Horton \& DeCelles 2001) or growth stratal patterns (e.g. Suppe et al. 1992; Ford et al. 1997).

In the present paper, the mode of propagation of foreland basins, loading/unloading cycles and the transition from underfilled to overfilled are investigated using the methods listed above, coupled with the structural study in the western Corbières (eastern North Pyrenean retro-foreland basin). In this area, two syncontractional basins differing in age (late Cretaceous and Eocene) and in geodynamic context ('fully' underfilled in front of a submarine wedge and underfilled to overfilled in front of an emerged wedge) are separated in time by a rather long period of tectonic quiescence (latest Cretaceous and Paleocene) and in place by a large basement duplex.

\section{Regional setting}

The Pyrenees constitute a narrow asymmetrical double-wedged range, including a relatively wide southern pro-foreland basin and a narrower northern retro-foreland basin. The Pyrenean range (Fig. 1a) is traditionally divided into five longitudinal structural zones striking $c$ N110E, which are from south to north:

(1) the south Pyrenean zone consisting of Mesozoic and Tertiary terranes and comprising the southern foreland basin;

(2) the Axial Zone essentially made up of Palaeozoic and pre-Palaeozoic terranes affected by Hercynian deformation and metamorphism;

(3) the North Pyrenean Zone comprising Mesozoic strata overlying the Hercynian basement locally exhumed to form the socalled North Pyrenean massifs; and

(4) the sub-Pyrenean zone in which Upper Cretaceous and Tertiary deposits overlie the Palaeozoic basement.

The Axial Zone, the North Pyrenean and subPyrenean Zones are separated from each other by two major faults, which are from south to north, the North Pyrenean Fault (NPF) and the North Pyrenean Frontal Thrust (NPFT). Eastwards, the general N110E trend of the structures changes to north-south in the Corbières bend (Virgation des Corbières).

The southern pro-foreland basin has long and intensely been studied from the double viewpoint of structure (ECORS Pyrenees Team 1988; Burbank et al. 1992; Muñoz 1992; Beaumont et al. 2000) and relationships between tectonics and sedimentation (Puigdefabregas \& Souquet 1986; Puigdefabregas et al. 1986; Specht 1989; Déramond et al. 1993; Williams et al. 1998; Vergés et al. 1998; Nijman 1998, amongst others). Studies of the tectonics-sedimentation relationship are less numerous in the northern retro-foreland basin (Baby et al. 1988; Razin 1989; Déramond et al. 1993; Brusset et al. 1997; Serrano et al. 2001). From a tectonic viewpoint, the essential difference between the southern proforeland basin and northern retro-foreland basin is that in the former the basal décollement is constituted by the Upper Triassic evaporites, whereas, in the latter, Palaeozoic strata and even metamorphic/plutonic basement are largely involved in the Alpine structures.

Our study area is situated between the Aude valley and the Corbières bend (Fig. 1). A particularly interesting feature of this area is that Palaeozoic rocks are involved in Alpine structures as far as in the distal parts of the foreland basin (Fig. 1b).

\section{Stratigraphy}

The Hercynian series is composed of a basement including a group of medium-pressure granulitefacies rocks overlain by HT-LP migmatites and metasediments and unmetamorphosed strata of Early to Late Palaeozoic age. In the study area, metamorphic and anatectic Hercynian rocks are only present in the south of the North Pyrenean zone (Bessède, Salvezines and Agly massifs, Figs 1 b \& 2). Only unmetamorphosed Middle Ordovician to Late Carboniferous strata are 

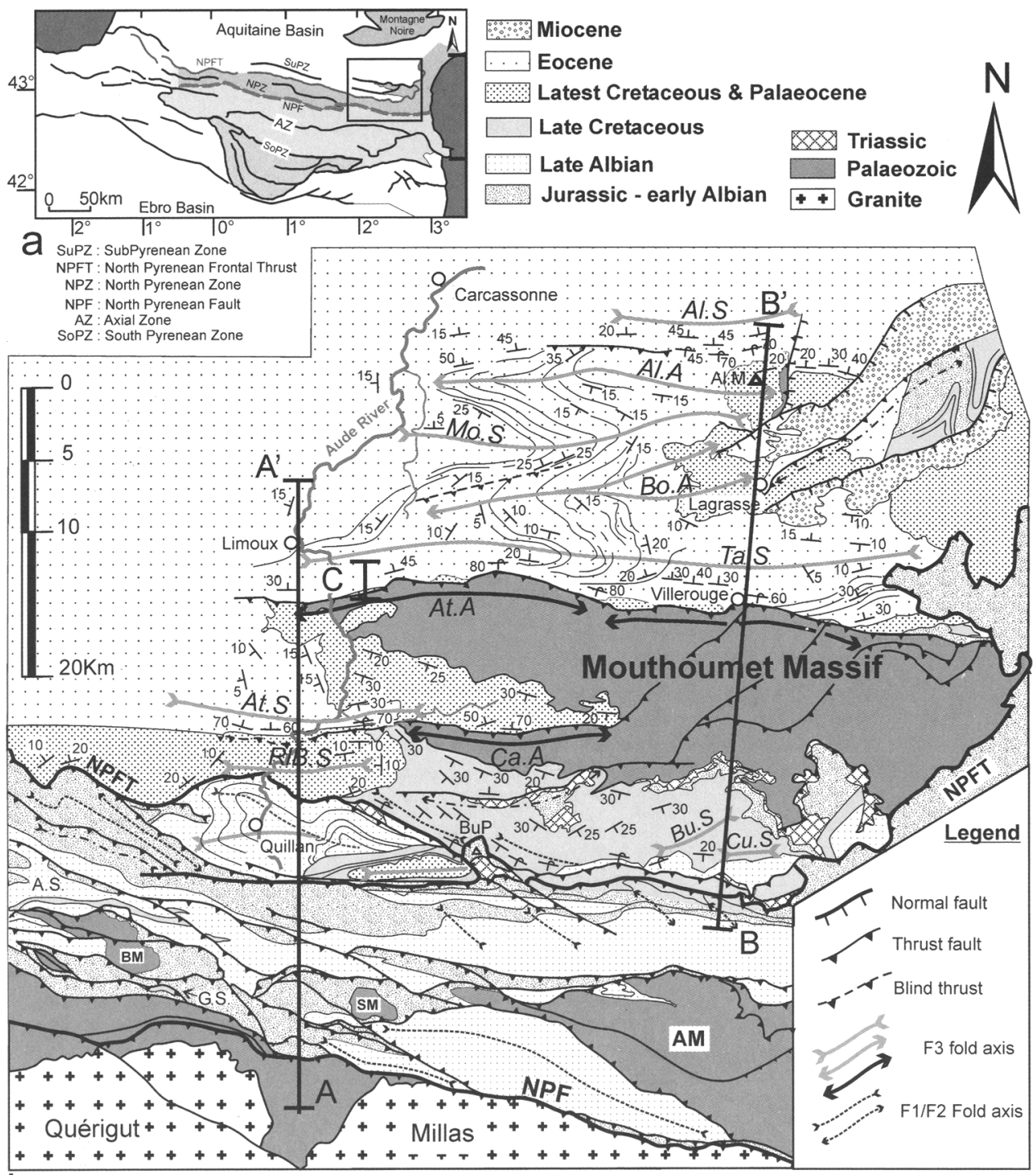

Fig. 1. (a) Location map. (b) Structural map of the studied area. AA' and BB' are the cross-sections shown in Fig. 2. C is the cross-section shown in Fig. 7. NPF, North Pyrenean Fault; NPFT, North Pyrenean Frontal Thrust; AM, Agly Massif; BM, Bessède Massif; SM, Salvezines Massif; A.S, Axat Syncline; Al.S, Alaric Syncline; At.S, Alet Syncline; BeS, Bezu Syncline; Bu.S, Bugarach Syncline; Cu.S, Cucugnan Syncline; G.S, Gesse Syncline; Mo.S, Montlaur Syncline; RIB.S, Rennes-les-Bains Syncline; Ta.S, Talairan Syncline; Al.A, Alaric Anticline; At.A, Alet Anticline; Bo.A, Boucher Anticline; Ca.A, Cardou Anticline; Al.M. Montagne d'Alaric; Bu.P, Bugarach peak.

observed in the sub-Pyrenean Zone (Mouthoumet and Alaric massifs). These were previously affected by flat-lying Hercynian thrusts (Arthaud et al. 1976; Bessière 1987; Bessière et al. 1989) reactivated during Alpine deformation (Bessière 1987; Bessière et al. 1989).
The Mesozoic series begins with a thin blanket of Lower Triassic sandstones and conglomerates often preserved in the Mouthoumet Massif. The Upper Triassic evaporite-bearing marls are widespread in the southern sub-Pyrenean Zone and northern North Pyrenean Zone, where they 


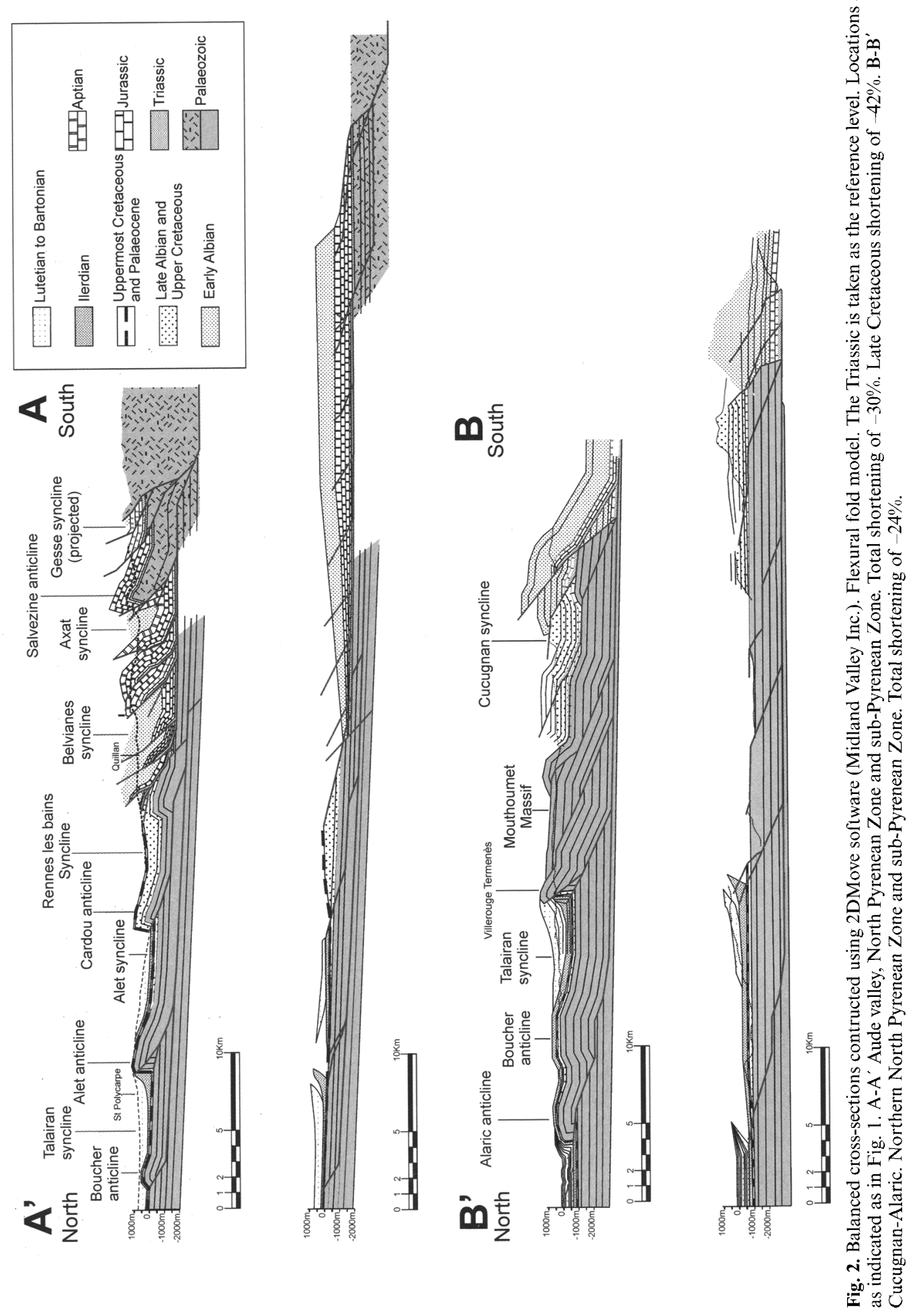


constitute the upper décollement, but are frequently lacking in the southern North Pyrenean zone. These are succeeded by Jurassic and Lower Cretaceous shallow marine carbonates and marls, 1000 to $1100 \mathrm{~m}$ thick (Wallez, 1974) only present in the North Pyrenean Zone and northeastern sub-Pyrenean Zone (Fig. 1b).

Upper Cretaceous strata crop out in two small areas at the vicinity of the North Pyrenean Fault (Gesse syncline) and north of the Bessède North Pyrenean Massif (Axat Syncline) and in a much wider area in the northern North Pyrenean Zone and southern sub-Pyrenean Zone (Fig. 1b). The Paleocene is represented by shallow-marine to non-marine deposits (Plaziat 1984, 1987; Tambareau et al. 1995).

The Eocene is represented by Early Ilerdian platform limestones, succeeded by deep marine deposits grading northwards to a shallow-marine platform of Middle to Late Ilerdian age, and then by a thick series of fluvial deposits known as the Palassou conglomerates, of Late Ilerdian (Crochet 1991) through Early to Middle(?) Bartonian age (Berger \& Rey 1990; Berger et al. 1993).

\section{Structure}

In the study area, the North Pyrenean Zone appears as a large-scale anticline with Hercynian rocks forming structural highs in its southern part (Figs 1b \& 2). To the south, the North Pyrenean Zone is overthrust by the Axial Zone along the North Pyrenean Fault which is likely to represent a major strike-slip fault (Choukroune 1976; Choukroune and Mattauer 1978) reactivated as a thrust fault (Soula et al. 1986). To the north, the North Pyrenean Zone overrides the sub-Pyrenean Zone along the North Pyrenean Frontal Thrust (Figs $1 \mathrm{~b} \& 2$ ). The internal structure is mainly determined by $\mathrm{N} 120-100 \mathrm{E}-$ trending folds, $F_{1}$, with half-wavelengths ranging from 1-2 km to $200-300 \mathrm{~m}$, subparallel to the overall direction of the range in the east (Leblanc and Vaudin 1984), but clearly oblique in the west (Soula et al. 1986). The $F_{1}$ folds are deformed by N135E to N110E-trending map-scale fold bands, $\mathrm{F}_{2}$, and associated smaller (c.200-300 $\mathrm{m}$ halfwavelength) en échelon folds (Soula \& Bessière 1980; Leblanc \& Vaudin 1984; Soula et al. 1986) (Fig. $1 b$ ). $F_{1}$ and $F_{2}$ folds have been interpreted as a result of left-lateral strike-slip shearing accompanying regional shortening (so-called 'transpression') (Soula \& Bessière 1980; Soula et al. 1986). $F_{1}$ and $F_{2}$ folds are north-verging fault-related folds, mostly fault-propagation folds, frequently related to blind thrusts passing sideways to merging thrust faults (Figs 1 b \& 2).
The fault-propagation folds are responsible for the general strata overturning which characterizes this area. To the north, the main décollement is constituted by the Triassic evaporites and the basement is not involved. To the south, the Triassic evaporites are often lacking and the décollement lies within the Hercynian migmatites, as shown by the involvement of these migmatites in the thrust structures (Fig. 2). In the Albian marls and Upper Cretaceous flysch, $F_{1}$ and $F_{2}$ folds are accompanied by minor folds associated in the southern area with foliations $S_{1}$ and $\mathrm{S}_{2}$ (Choukroune \& Meurisse 1970; Wallez 1974; Choukroune 1976). The $F_{1} / F_{2}$ folds and thrusts are unconformably overlain by Campanian and younger strata (Mattauer \& Proust 1965) and locally overriden by c.east-west to ENEWSW-trending thrust faults and related folds, $\mathrm{F}_{3}$ (Fig. 1b).

In the northern sub-Pyrenean Zone, only the $\mathrm{F}_{3}$ longitudinal folds are present and deform the Palaeozoic as well as the Paleocene and Eocene strata (Figs 1 b \& 2). These folds are either faultpropagation folds associated with overturned through shallow-dipping Paleocene and Eocene growth strata (Mouthoumet-Talairan or Alaric), or open fault-bend folds with gently dipping limbs lacking growth stratal patterns (BoucherMontlaur). In the eastern Mouthoumet Massif, the east-west-trending and moderately dipping longitudinal thrusts faults branch on to reactivated pre-existing Hercynian subhorizontal thrust faults similarly showing $\mathrm{S}-\mathrm{N}$ tectonic transport (Fig. 1b).

\section{Relationship between tectonics and deposition}

\section{Late Cretaceous and Paleocene}

The Late Cretaceous deposits crop out discontinuously in the southern North Pyrenean Zone and continuously in the the northern subPyrenean Zone, whereas the latest Cretaceous and Paleocene deposits are observed all over the sub-Pyrenean Zone. These deposits have a total thickness varying from $c .800 \mathrm{~m}$ in the Quillan/Rennes-le-Château area to less than 80 $\mathrm{m}$ in the north, and represent the infill of the eastern termination of the Late Cretaceous 'flysch' basin which is much wider and deeper westwards (e.g. Déramond et al. 1993; Razin 1989; Brusset et al. 1997; Serrano et al. 2001).

The stratigraphy of the Late Cretaceous and Paleocene deposits has been intensely studied for the past 30 years (e.g. Gélard 1969; Wallez 1974; Bilotte 1985, 1992; Pélissier 1987; Bessière et al. 1989; Tambareau et al. 1995), which provides an excellent age control. Modern sequence strati- 
graphy and sedimentary facies studies are, however, rather recent and concern only the Coniacian, Santonian and Early Campanian depositional systems (Wallez-Fondecave and Souquet 1991). The following is a comprehensive description of the Late Cretaceous and Palaeocene cycle, including the middle Cenomanian to Turonian and the Latest Cretaceous and Paleocene depositional units (Fig. 3). The sedimentological and sequence analyses in the Coniacian to Early Campanian are derived from those of Wallez-Fondecave and Souquet (1991), including Bilotte's (1992) stratigraphic revision and also the personal observations of the present authors.

Middle Cenomanian and Turonian. In the south, Middle Cenomanian to Turonian deposits have been recognized in front of the Axial Zone Thrust (Magné and Mattauer 1968; Wallez 1974) and in front of the Bessède-Salvezines thrust fault (Bilotte et al. 1973; Wallez 1974; Bilotte 1985). In front of the Axial Zone, these deposits are unconformably resting over Jurassic, Lower
Cretaceous and Upper Albian strata deformed by a fault-related syncline (Gesse Syncline; Wallez 1974), although being themselves deformed by the same syncline. The series commences by highly heterometric and poorly sorted breccias containing Jurassic through Aptian clasts up to $c .1 \mathrm{~m}^{3}$ in size, derived from the southern limb of the Gesse Syncline, included in a calcareous-marly matrix $(50 \mathrm{~m})$. These breccias are succeeded by carbonate turbidites consisting of a repeated succession of calcareous microbreccias, laminated calcarenites and hemipelagic muds $(60 \mathrm{~m})$. This sequence overlying an erosional intra-foredeep unconformity denotes retrograding characteristics (a facies trend from debrite-turbidite couplet B to BC4, see Souquet et al. 1987) indicating slope and base-of-slope environments. This facies association indicates normal persistent turbiditic then hemipelagic deposition and then catastrophic processes such as episodic slope failure and large-scale debris-to-turbidite flows related to tectonic slumping and disruption (Souquet et al. 1987; Brusset et al. 1997). In front of the

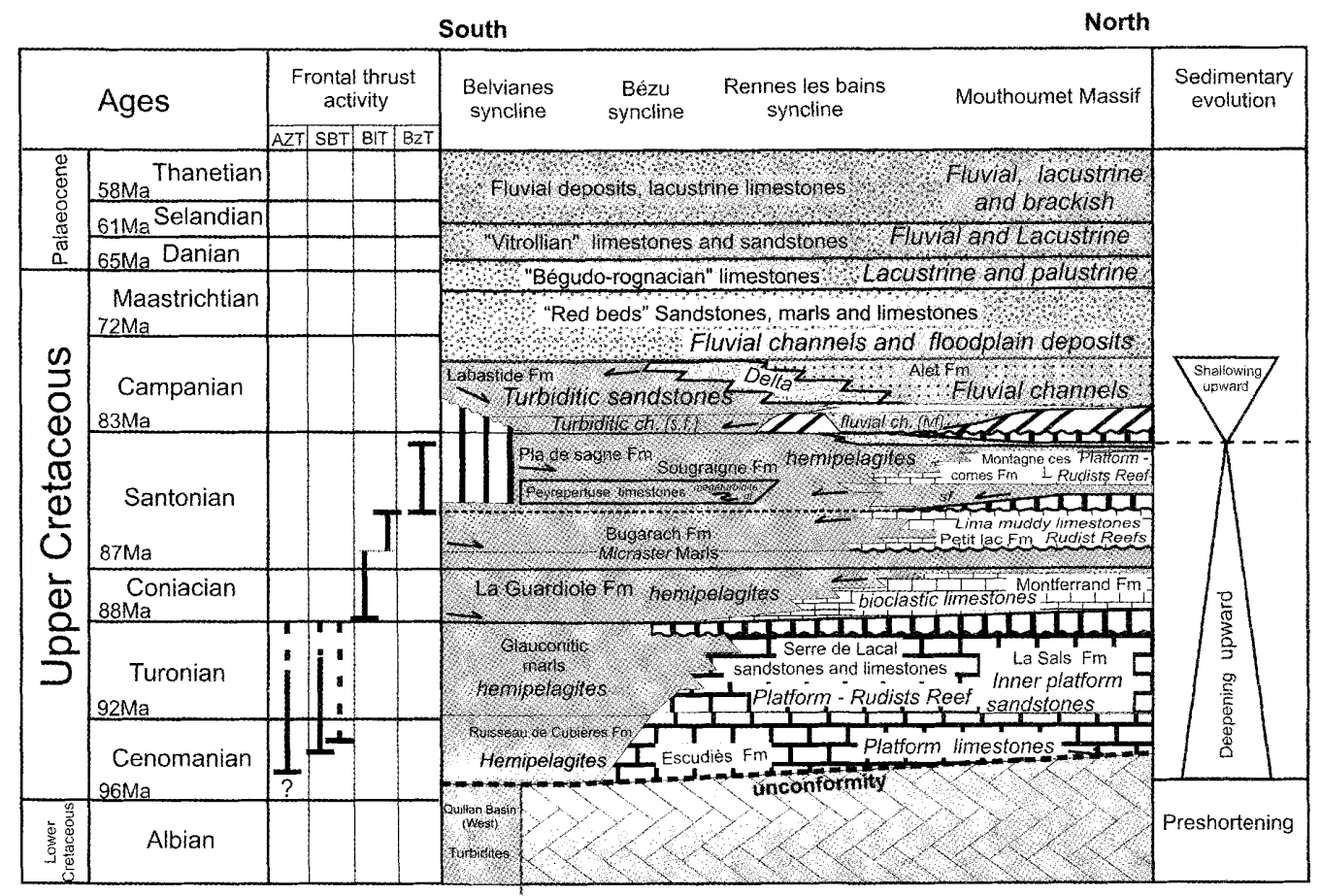

Fig. 3. Chronostratigraphic diagram of the late Cretaceous and Paleocene of the northern North Pyrenean Zone and the sub-Pyrenean Zone. Age scale after Odin (1994). No scale for Maastrichtian to Thanetian. AZT, Axial Zone Thrust (North Pyrenean Fault); SBT, Salvezines-Bessède Thrust; BIT, Belvianes Thrust; BzT, Bezu Thrust; gf, glide features; ivf, incised valley fill; s.f., slope fan. Arrows indicate sense of sediment transport. Data after Wallez-Fondecave \& Souquet (1991); Bilotte (1992); Freytet (1970), and the personal observations of the authors. 
Bessède-Salvezines-Agly thrust fault propagation fold (Axat Syncline), the same turbiditic system is observed (Bilotte et al. 1973; Wallez 1974). The basal erosional/unconformable contact here cuts across the Albian, but not the older strata of the overturned limb, and only Albian clasts are found in the basal breccias. This indicates that the deposits here were less mature than in the south. Olistoliths of Neocomian age observed within the upper part of the breccias (Bilotte et al. 1973; Wallez 1974) indicate, however, that erosion then penetrated deeper in the folded strata, but without reaching the Jurassic.

In the northern North Pyrenean/southern sub-Pyrenean Zones, the Middle to Late Cenomanian is represented in the QuillanCucugnan area by lower platform micritic limestones and white marls (Bilotte 1985) unconformably overlying the Late Albian strata (Gélard 1969), and still more to the north, by platform limestones deposited over an erosion surface cutting the Palaeozoic strata of the Mouthoumet Massif. The Turonian is represented by glauconitic marls (hemipelagites) indicating deep-water environments, passing northwards to mixed-platform deposits including reefal carbonate intervals interbedded with channelled sandstones representing shoreface facies (Serre de Lacal Formation; Bilotte 1985), and then to inner platform sandstones (La Sals Formation) onlapping the Mouthoumet High. This indicates a retrogradational evolution and thus a northwards migration of the platform, from the Middle Cenomanian to the Turonian (Fig. 3). The mixed and inner platforms were supplied with fine- and medium-grained clastics by the emerged Mouthoumet High, as shown by the nature of these clasts (quartz, Ordovician quartzitic pelites, Carboniferous black cherts). On the northern side of the Mouthoumet High, Turonian lignite-bearing dark clays representing lagoonal-brackish deposits have been observed unconformably resting on the Palaeozoic (Freytet 1970; Bilotte 1985).

Coniacian and early to middle Santonian. These deposits are observed between the BelvianesCucugnan Syncline and the Mouthoumet High (Fig. 3). The basal erosional unconformity cuts across the Turonian, Cenomanian and Upper Albian strata of the southern flank of the WNW-ESE-trending $\left(\mathrm{F}_{1} / 2\right)$ Belvianes Syncline (Gélard 1969; Wallez-Fondecave \& Souquet 1991) in the south, and is marked in the north by Palaeozoic clast-bearing conglomerates infilling erosional scours. In the south, the deposits are fine-grained clastics and marls, in which three sequences characterizing slope and basin deposition have been recognized, each of them showing the succession of clay-rich bioclastic/ sandy turbidites and homogeneous marls (WallezFondecave \& Souquet 1991). Palaeocurrents in the turbidites have approximately east-to-west directions indicating drainage parallel to the axis of the syncline (longitudinal flow: Burbank 1992; Jordan 1995). These turbidites include detritus of marls and planktonic microfaunas of Upper Albian age originating from the reworked southern limb of the fold (Wallez-Fondecave \& Souquet 1991). In the north, the Coniacian and Early/Middle Santonian is represented by two retrograding depositional sequences, each including platform carbonates succeeded by a condensed section and offshore marls (WallezFondecave \& Souquet 1991). According to Wallez-Fondecave \& Souquet (1991), these two sequences are correlated with the two upper southern sequences - the lowermost southern sequence corresponding with the basal erosional surface.

Middle to Late Santonian. These deposits are absent to the south of the North Pyrenean Frontal Thrust where the Latest Santonian/Early Campanian strata directly overlie the Early to Middle Santonian deposits. In front of the North Pyrenean Frontal Thrust, the deposits are homogeneous blue marls (Pla de Sagnes and Sougraigne Marls), c.300 m thick, infilling the WNW-ESE-trending Rennes-les-Bains Syncline and conformably resting on the Early to Middle Santonian marls (Fig. 3). At the eastern termination of the syncline near Cucugnan, the marls include a $50 \mathrm{~m}$ thick unit of calcarenites and bioclastic limestones containing rudist reefs, of Middle/Late Santonian age (Bilotte 1992). These limestones are affected by mesocopic slump folds, the asymmetry of which indicates top-to-the-north sliding. We interpret this unit as an earthquake-induced megaturbidite (Souquet et al. 1987), issuing from an unstable southern platform. In the north, the depositional sequence commences with an erosional unconformity overlain by offshore marls and channelled sandstones showing east to west palaeo-flows (Wallez-Fondecave \& Souquet 1991). These are succeeded by a group of three parasequences (Montagne des Cornes; Bilotte 1985, 1992) showing an overall transgressive stacking pattern. The sequence ends with transitional shoreface argilites (Wallez-Fondecave \& Souquet 1991) (Fig. 3).

Latest Santonian to Early Campanian. These deposits are observed all over the northern 
North Pyrenean Zone (Quillan area) and in the sub-Pyrenean Zone to the south of the Mouthoumet Front, widely onlapping the older Late Cretaceous strata. In the south (Quillan and Cucugnan areas), the basal erosional unconformity cuts across the Santonian, Coniacian and Turonian strata (Fig. 3). The early deposits are parts of a slope fan turbiditic system (Labastide Sandstones; Bilotte 1985, 1992) constituted by marls and channelled sandstones showing longitudinal palaeo-flows toward the west (Wallez-Fondecave \& Souquet 1991). Clasts originating from the northern Mouthoumet High, and clasts, olistoliths or olistostroms originating from the south (e.g. Middle Santonian limestones) are embedded in these deposits. The upper part of the formation is constituted by turbiditic marls interbedded with thin sandstones beds, which can be related to pro-delta facies (Pélissier 1987). In the north, the erosional basal unconformity cuts across the Middle to Late Santonian series (Bilotte, 1985, 1992; Wallez-Fondecave \& Souquet 1991) and the Latest Santonian/Early Campanian strata directly overlie the Palaeozoic of the Mouthoumet Massif. The deposits are coarse-grained clastics infilling incised fluvial valleys, succeeded by fining-upward fluvial deposits (Alet Sandstones). Therefore, in contrast with the preceding systems, the Latest Santonian-Early Campanian system displays a shallowing upward stacking pattern (Fig. 3).

Late Campanian, Maastrichtian and Paleocene. The Late Campanian to Maastrichtian deposits rest conformably over the Early Campanian continental (Alet Sandstones) and marine (Labastide Sandstones) deposits of the southern sub-Pyrenean Zone and unconformably over the folded Albian and Aptian strata (Cucugnan Anticline). In the north, these deposits were deposited over the Palaeozoic substrate, widely onlapping the Alet sandstones (Mouthoumet and Alaric massifs). In the studied area, the sedimentation remained continental to lagoonal. The major part of the sediment corresponds with 'red beds' (known as 'Garumnian facies') comprising fine-grained fluvial floodplain deposits changing laterally to lacustrine/palustrine marls and limestones. The preserved channels are rather thin and most often fine grained. Conglomerates are observed at the base of three fining- and thinning-upward and downstream sequences, the two lower ones corresponding with the Begudian/Rognacian facies and the upper one to the Vitrollian facies (Freytet 1970). In the north (Alaric region), clastic material was derived from the north (Montagne Noire), the south (Mouthoumet High) and local sources. In the south (Rennes-les-Bains-Cucugnan) the clasts are derived from multiple sources in the whole North Pyrenean Zone (Freytet 1970). Provenance and palaeocurrent studies indicate south to north transport, that is, transverse drainage. In the lower part of the series ('Begudo-Rognacian' facies) only clastic material derived from the northern North Pyrenean Zone has been observed (Freytet 1970). In the upper part of the series ('Vitrollian' facies), clasts of metamorphic Mesozoic carbonates issued from the southern North Pyrenean Zone are common in the west of the studied area, but no Palaeozoic rocks originating from the North Pyrenean massifs have been observed (Freytet 1970; Plaziat 1984). The Thanetian is essentially represented by lacustrine/palustrine/lagoonal limestones, where three marine transgressions have been identified, succeeded by floodplain deposits including fine-grained thin and narrow fluvial channels (Tambareau et al. 1995).

\section{Eocene cycle}

Eocene strata crop out from the Mouthoumet Massif to the Montagne Noire (Fig. 1b). The depocentre of the Early Eocene marine strata (Early to Late Ilerdian) is situated in front of the Mouthoumet Duplex (Talairan Syncline), whereas the depocentres of the Middle to Late Eocene continental deposits are situated in front of the Mouthoumet Duplex and Alaric thrustrelated fold (Talairan and Alaric Synclines) (Figs $2,4 \& 5)$.

The Ilerdian marine series. The lower unit of the Ilerdian marine series is constituted by foraminiferal and bivalve-bearing shelf carbonates ('basal marine limestones'; Doncieux 1912; Massieux 1973; Pautal 1985), 20-25 m thick, of earliest Ilerdian age (Shallow Benthic Zone 5; Serra Kiel et al. 1998). The middle unit is represented by silty to sandy marls and mediumgrained sandstones (Rey \& Bousquet 1981; Plaziat 1984; Pautal 1985; Tambareau et al. 1995) termed hereafter Blue Marls. The upper unit is represented in the north by tidal/ lagoonal/continental sandstones usually termed Oyster Sandstones, laterally changing southwards to coarser-grained sandstones and conglomerates - first marine and then continental. The average deposition rate was $0.16 \mathrm{~mm} /$ year in the depocentre, and only $0.08 \mathrm{~mm} / \mathrm{year}$ in the north of the basin (Montlaur) (Figs $4 \& 5$ ).

Two depositional sequences have been distinguished: The lower Blue Marls, of Early to Middle Ilerdian age (SBZ 6 and 7 and early SBZ 


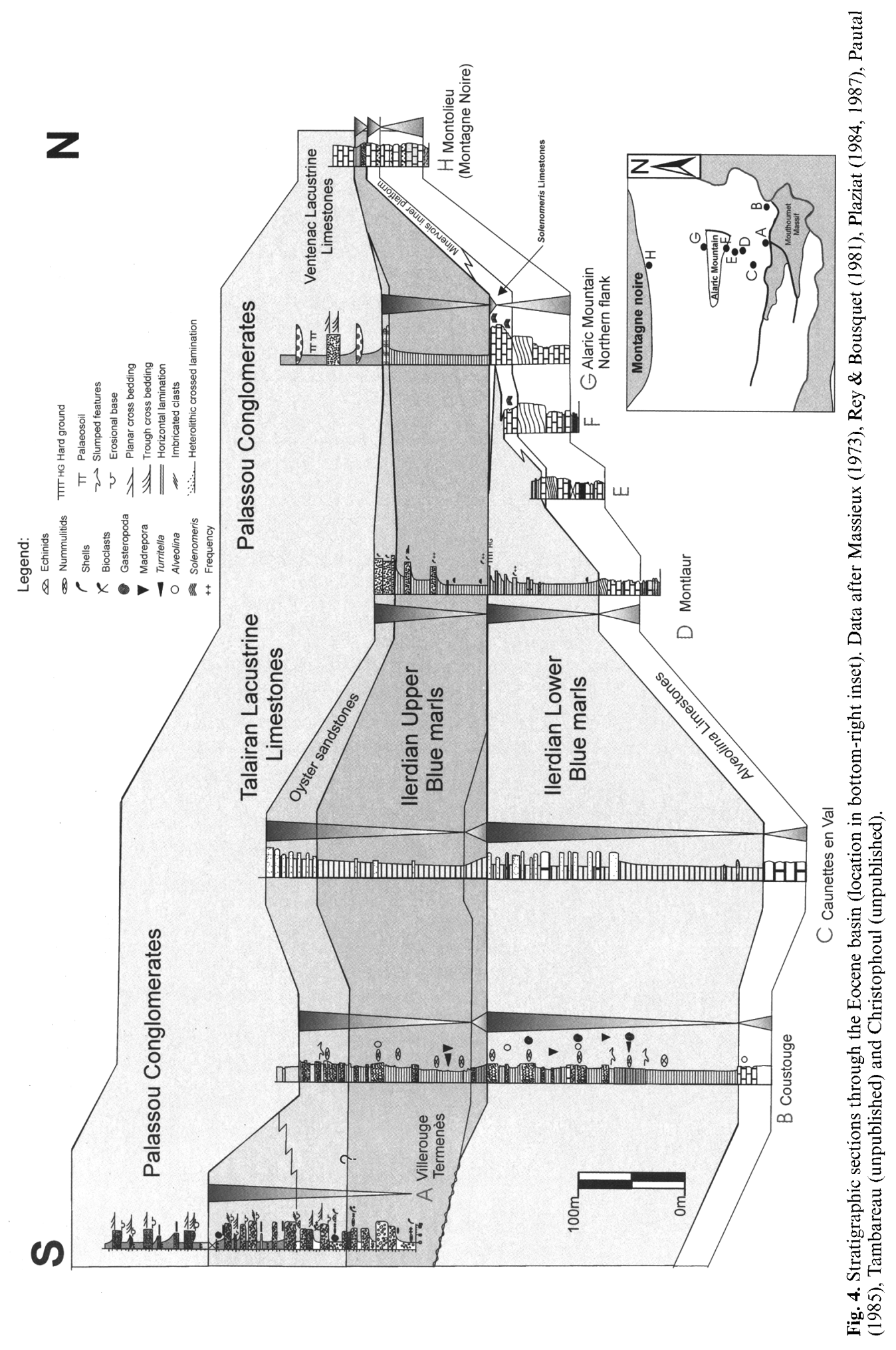




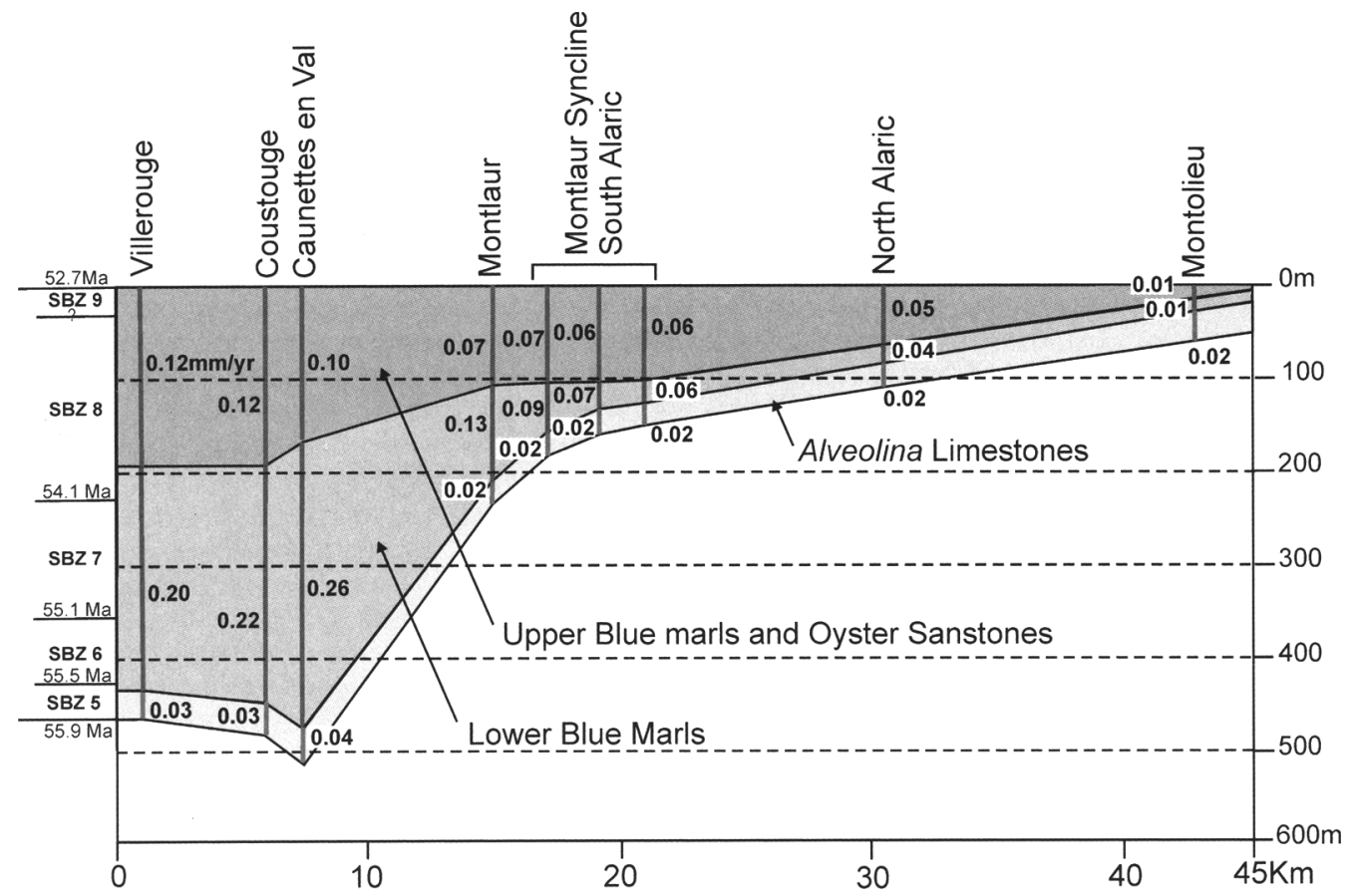

Fig. 5. Thicknesses and subsidence rates (mm/year) of the Ilerdian formations computed using Einsele's (1992) backstripping treatment. Water depths estimated after Pautal (1985). Ages of the boundaries between the shallow benthic zones (SBZ) after Serra Kiel et al. (1998).

8) and the Upper Blue Marls and Oyster Sandstones of Middle Ilerdian age (middle SBZ 8). Palaeoenvironmental analyses (Rey \& Bousquet 1981; Plaziat 1984; Pautal 1985) have shown that the upper part of either sequence formed a prodelta slope or an inner lagoon within a deltaic environment fed from the south. The transport of shallow-water fossils (Alveolinae and corals) into deeper-water environments (Plaziat 1984) reflects the poor stability of the slope in the vicinity of the orogenic wedge (Fig. $8 b)$. In the centre of the basin, the marls are enriched in planktonic foraminifera and impoverished in siliciclastics, and the grain size is markedly finer at any given level, which indicates a reduced siliciclastic supply from the orogen, coupled with increased water depth (Pautal 1985). Stratal growth patterns, including wedging, intra-formational unconformities, growth onlaps or, more rarely, growth offlaps (see Ford et al. 1997) are observed at the contact with the Mouthoumet front. The bases of both sequences are marked by major growth onlaps (Figs $4,6 \&$ 7).

The Lower Blue Marls overlie the basal limestones unconformably in front and on top of the
Mouthoumet front (Figs $6 \& 7$ ) and conformably in the southern depocentre and the north (Fig. 4). In the southern depocentre, these are represented by a thick coarsening/shallowing-upward sequence, $170 \mathrm{~m}$ thick, ended by a conformable transgressive surface. In the centre (Montlaur; Fig. 4), the coarsening upward sequence is only c. $85 \mathrm{~m}$ thick and ends with a hardground. In the north (Alaric), the Lower Blue Marls change laterally to platform limestones (Pautal 1985). These limestones, $40-80 \mathrm{~m}$ thick, of early Middle Ilerdian age (SBZ 6 and 7) become richer in siliciclastics towards the top and represent the outer platform (outer part of the 'Minervois platform'). In the inner platform, marls and sandy limestones containing quartzofeldspathic detritus derived from the north (Montagne Noire) are intercalated in the platform limestones. Two deltas have been identified (Issel and Caunes Minervois; Seguier 1972; Plaziat 1984). The scarcity of sand grains within the Lower Blue Marls south of the Alaric Mountain (Plaziat 1987) shows that the sandy sedimentation derived from the Montagne Noire did not overlap the edge of the platform, which indicates longitudinal drainage in the inner platform. The 


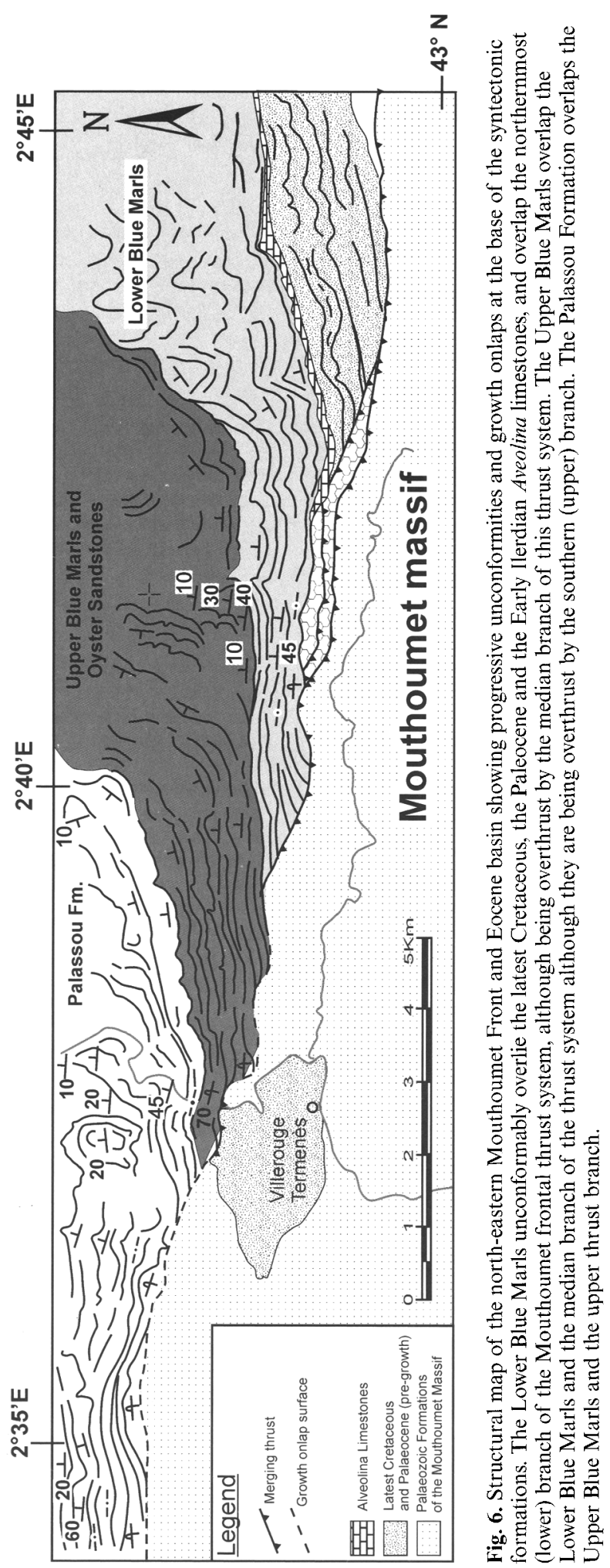




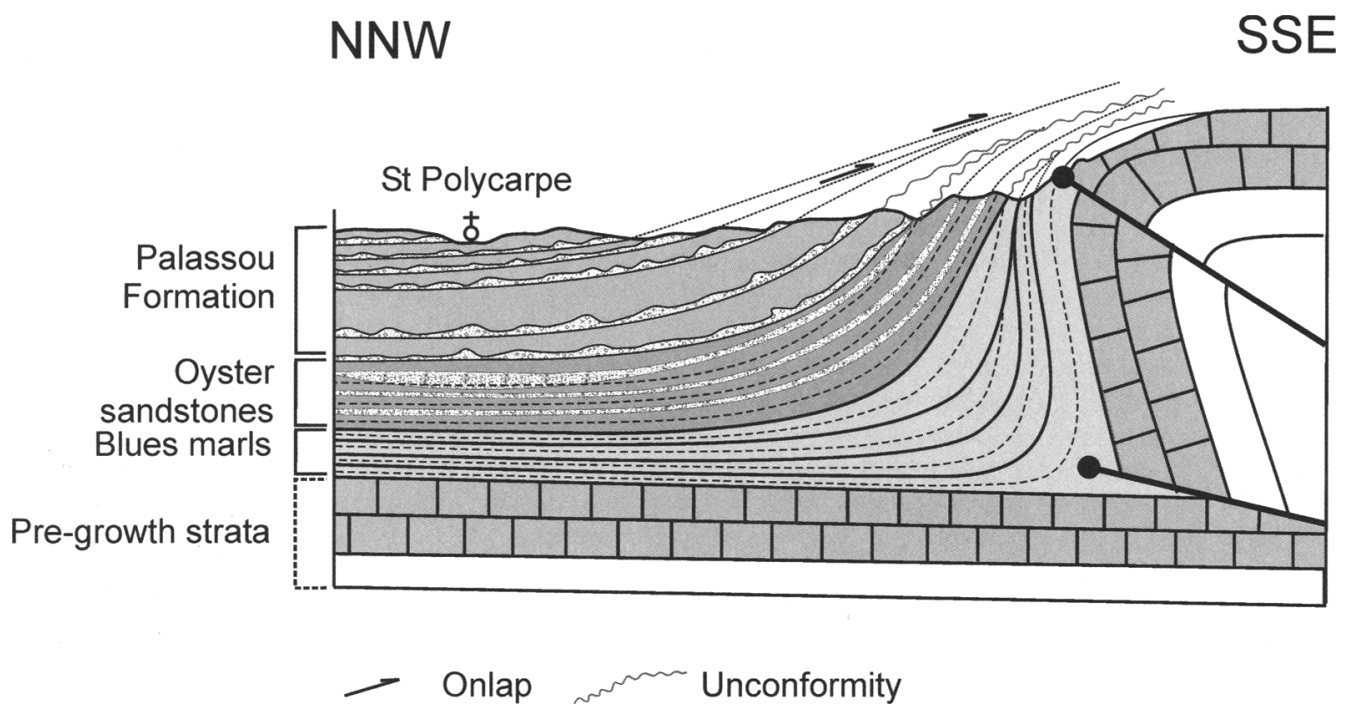

Fig. 7. Cross-section through the north western Mouthoumet Front showing growth structures involving the Blue Marls and Palassou Fotmsyion (see location in Fig. 1).
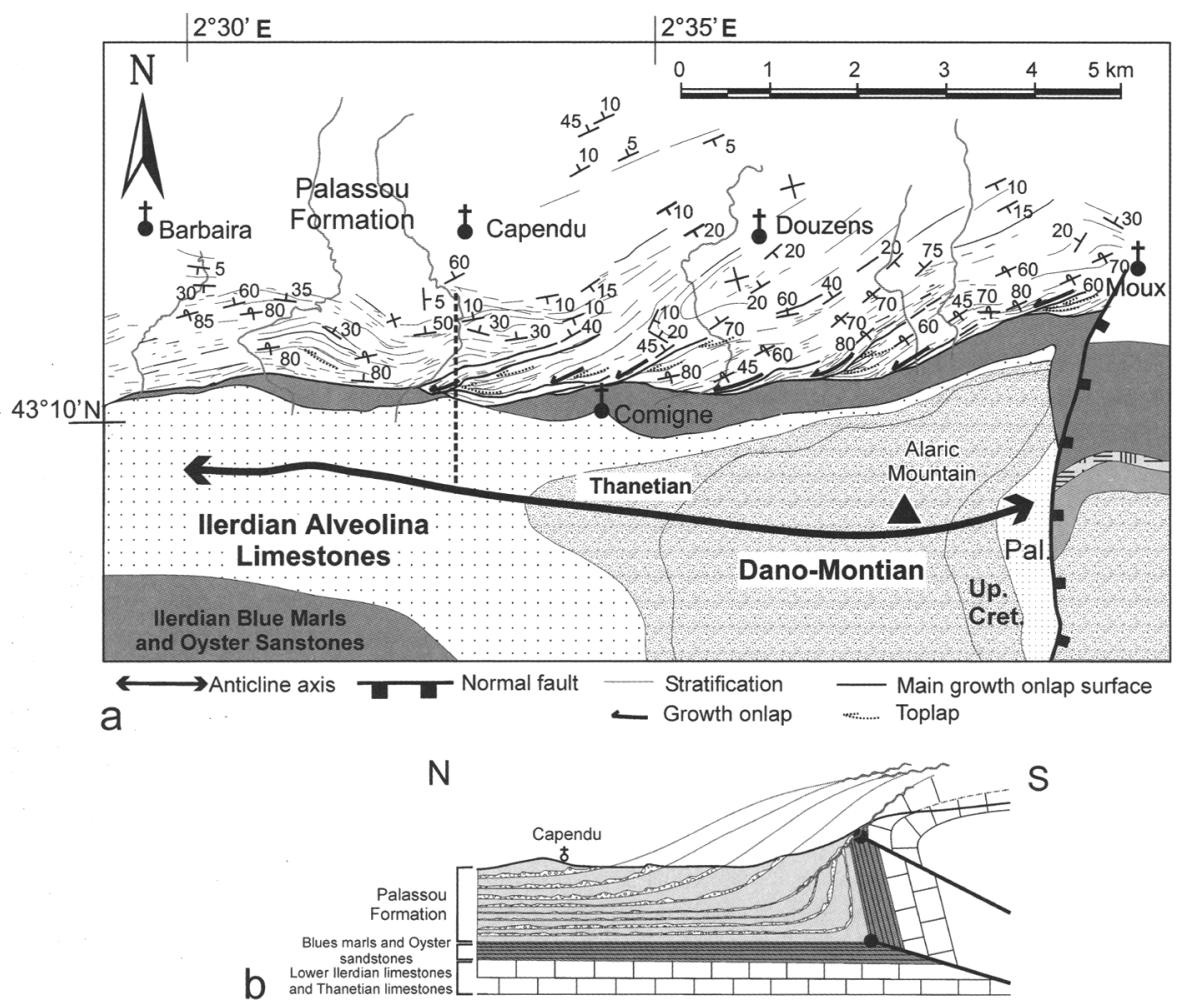

Fig. 8. (a) Structural map of the northern flank of the Alaric Anticline. The basal contact of the Palassou Formation is constituted by six major growth onlaps. Bed dip changes from overturned to shallow in $c .1 \mathrm{~km}$. (b) Cross-section showing the growth structures involving the Palassou Formation but not the Upper Blue Marls and Oyster Sandstones (interrupted line in (a)). 
shelf-break is likely to have been situated near the present hinge of the Alaric Anticline - to the north of which Solenomeris reefs rimmed the platform, and to the south of which carbonate clasts and slipped blocks, including Solenomeris originating from this platform, are embedded in the Lower Blue Marls (Plaziat, 1987). Subsidence rates varied from $0.20-0.26 \mathrm{~mm} / \mathrm{year}$ in the foredeep to $0.06 \mathrm{~mm} / \mathrm{year}$ near the shelf break and 0.04 to 0.01 in the inner platform (Fig. 5).

The Upper Blue Marls and Oyster Sandstones sequence unconformably overlies the Lower Blue Marls and the Palaeozoic strata on top of the Mouthoumet Front (Figs 4, 6\& 7). In the southern depocentre, the basal contact is conformable and the deposition commences with a fining/deepening-upward parasequence, $15 \mathrm{~m}$ thick, succeeded by a thicker $(c .95 \mathrm{~m})$ coarsening/shallowing upward parasequence set (Fig. 9). The Oyster Sandstones which form the upper part of this parasequence set are made up of thicker (up to $1 \mathrm{~m}$ ) and coarser-grained sandstone banks, and occasional conglomeratic lenses (Plaziat 1984) recording the northwards progradation of the deltaic system. Recognition of a Gilbert delta (Gilbert 1885; Nemec \& Steel 1988; Reading \& Collinson 1996) with palaeo- currents showing northwesterly, northerly and northeasterly sediment dispersal (Figs 4 \& 9) indicates increased progradation. In the centre (Montlaur), the southern basal fining/deepeningupward parasequence set is absent. The coarsening/shallowing upward sequence is only $100 \mathrm{~m}$ thick. The Oyster Sandstones are predominantly medium-grained deltaic sandstones. In the north, the Upper Blue Marls overlap the former shelf-break and rest on the Solenomeris limestones. The deposits are richer in siliciclastic grains originating from the northern craton. On the northernmost margin of the basin, the Upper Blue Marls change laterally to more or less sandy lagoonal marls, several metres thick, containing beds of lacustrine limestones and sandstones (Valeron Marls; Seguier 1972; Plaziat 1987). The Oyster Sandstones are represented by tidal/lagoonal/continental fine- to mediumgrained sandstones northwards onlapping the pre-Ilerdian strata. Subsidence rates vary from $0.10-0.12 \mathrm{~mm} /$ year in the foredeep to $0.05-0.01$ $\mathrm{mm} /$ year near the craton (Fig. 5).

The Palassou formation. In the studied area, the continental Palassou Formation commences with the Late Ilerdian (SBZ 8-9) (Crochet 1991;

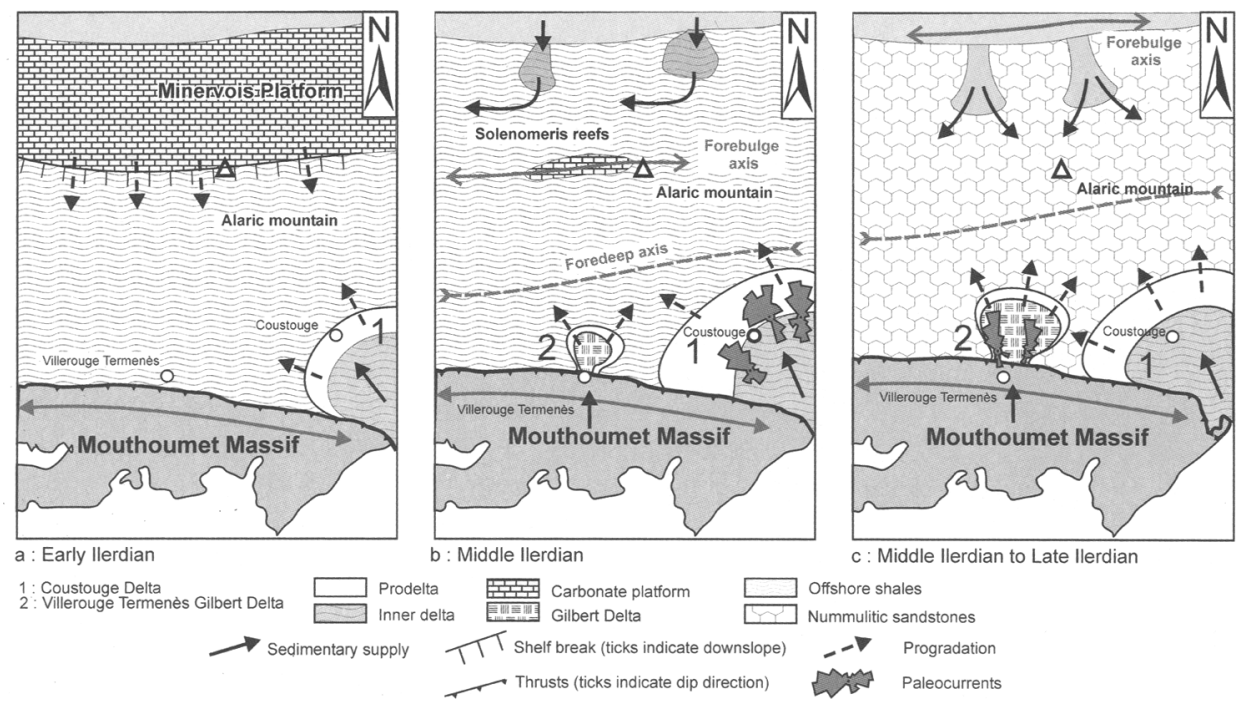

Fig. 9. Schematic evolution of the Ilerdian basin. (a) Early Ilerdian. Early Lower Blue Marls. A flexural basin initiates as a result of first step wedge advance. Clastic deposits are delivered by clastic deltas at outlets of major rivers coming from the wedge. (b) Late Lower Blue Marls. Foreland basin system is developed as a result of ongoing wedge advance. The forebulge separates the foredeep, fed by clastic deltas derived from the wedge, from the backbulge depozone draining deltas derived from the craton (Montagne Noire). (c) Middle to Late Ilerdian. Upper Blue Marls and Oyster Sandstones. Following tectonic quiescence, renewed wedge advance is responsible for basin widening and forebulge migration. The foredeep is now fed by deltas derived from both the craton and the orogen. A Gilbert delta forms at the outlet of a river that is incising the fault escarpment. 
Berger et al. 1997). Only the lower part of the Palassou Formation is exposed here. The youngest strata dated from fossil evidence are exposed in the north and give early middle Bartonian ages (Plaziat 1987; Berger and Rey 1990). The total thickness can be evaluated there to more than $1000 \mathrm{~m}$. Because no facies and architectural analyses have been yet published, this formation will be described here more thoroughly.

The Formation consists predominantly of marls and siltstones representing floodplain deposits. These are often pedogenetically modified, frequently showing rooted palaeosols, and contain thin, poorly incised and sheet-like (20-50 $\mathrm{m}$ wide, $1-10 \mathrm{~m}$ thick) sandstone-filled channels representing 'elements SB' of Miall (1996). The lithofacies consist mainly of $\mathrm{St}, \mathrm{Sp}$ and less frequently Sh and Sl. Lateral accretion sets (LA elements) with cross-bed foresets up to 1-2 m high are common. Occasionally, the sand bodies are incised by narrower channels with a concaveup erosional base filled with sands and gravels rarely larger than $5 \mathrm{~cm}$ grain size, containing lithofacies Ss/Se, St, (Gt) and Sp. Very locally, coarser-grained conglomerates (maximum grain size $>50 \mathrm{~cm}$ ) filling deeper channels have been observed (Plaziat, 1987). On the scale of the entire formation, the deposits are coarsening upwards and westwards and fining northwards. The spacing of the channels is in general rather wide (some hundreds of metres). In the south, the channels are oriented roughly SSE-NNW (Plaziat 1984). On the northern margin, the directions of the palaeocurrents are SSE-NNW, south-north and, more rarely, east-west and south-north (Plaziat 1987; Berger and Rey 1990). The volumetric importance of the floodplain deposits and the lateral accretion patterns have led us to interpret the fluvial system as sandy meandering rivers. At any level and from south to north, the clasts are predominantly Mesozoic rocks (Berger and Rey 1990) originating from the Late Cretaceous basin and the North Pyrenean thrust sheets, and unmetamorphosed Palaeozoic rocks originating from the Mouthoumet massif. No southerly-derived granitoid or metamorphic Palaeozoic clasts are observed. Even in the northern margin, the northerly-derived materials are rare.

Small bodies of palustrine limestones are scattered throughout the whole formation (Figs 4 \& 10). Much larger palustrine/lacustrine limestone and marl complexes are seen in the central part of the Talairan Syncline, where they are more than 20-30 m thick and crop out over areas of some square kilometres, and all over the northern margin where they have been mapped as two distinct units, 20 to $150 \mathrm{~m}$ thick (Ventenac and Agel limestones; Plaziat 1987; Berger and Rey 1990). There limestones pass laterally to, either lagoonal marls and deltaic sandstones/ sandy marls, or fluvial sandstones (Plaziat 1987). Although the small bodies are likely to represent ephemeral overbank ponds or backswamps, the larger complexes can be considered as perennial. The Talairan Complex was the lateral equivalent of the lower part of the fluvial formation, and probably represented a swampy topographic depression between the Mouthoumet and Alaric highs. The northern complex persisted later and may be interpreted as a large longitudinal depression open to the west (Aquitaine marine basin), more or less swampy, which constituted the terminating environment of the fluvial system, as shown by the direction and sense of the palaeocurrents. The intercalations of lagoonal marls indicate that this depression remained with an altitude slightly above or below sea-level. The whole system may be interpreted as a shallow-slope meandering fan (similar to the middle-upper part of the 'losimean' model of Stanistreet and McCarthy 1993). The ubiquity of detritus derived from the orogen and the SSE-NNW direction of the channels, suggest multiple coalescing fans distributed by numerous outlets beyond the Mouthoumet frontal thrust.

The growth strata exposed at the contact of the active Mouthoumet frontal thrust are in continuity with those in the Ilerdian. Erosional unconformities associated with growth onlaps (Ford et al. 1997) and strata wedging are observed (Figs 6 \& 7). To the north, growth strata are fairly well exposed at the contact of the Alaric Anticline. These developed there entirely in the Palassou Formation, where six intraformational unconformites and growth onlaps have been recognized (Fig. 8). As in the southern Pyrenean foreland basin (e.g. Ford et al. 1997), an upward change in dip from overturned to $15-10^{\circ}$ and the progressive disappearance of strata wedging indicate that the growth folds decrease in amplitude upwards, so as to die out with the deposition of the younger exposed strata. Fold decay is also shown by the disappearance of the Talairan swamp.

\section{Interpretation}

\section{Late Cretaceous and Palaeocene}

Middle Cenomanian to Late Santonian. During Middle Cenomanian to Turonian times, the catastrophic sedimentation resulting from tectonic sloping and disruption of the forelimbs of the Gesse and Bessède-Salvezines anticlines together with the deformation of the basal erosional unconformity cutting across these 


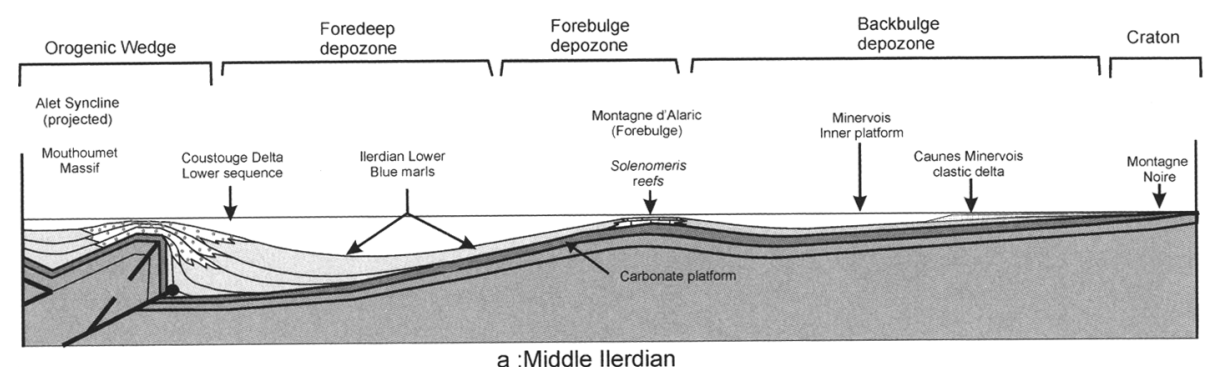

a :Middle llerdian
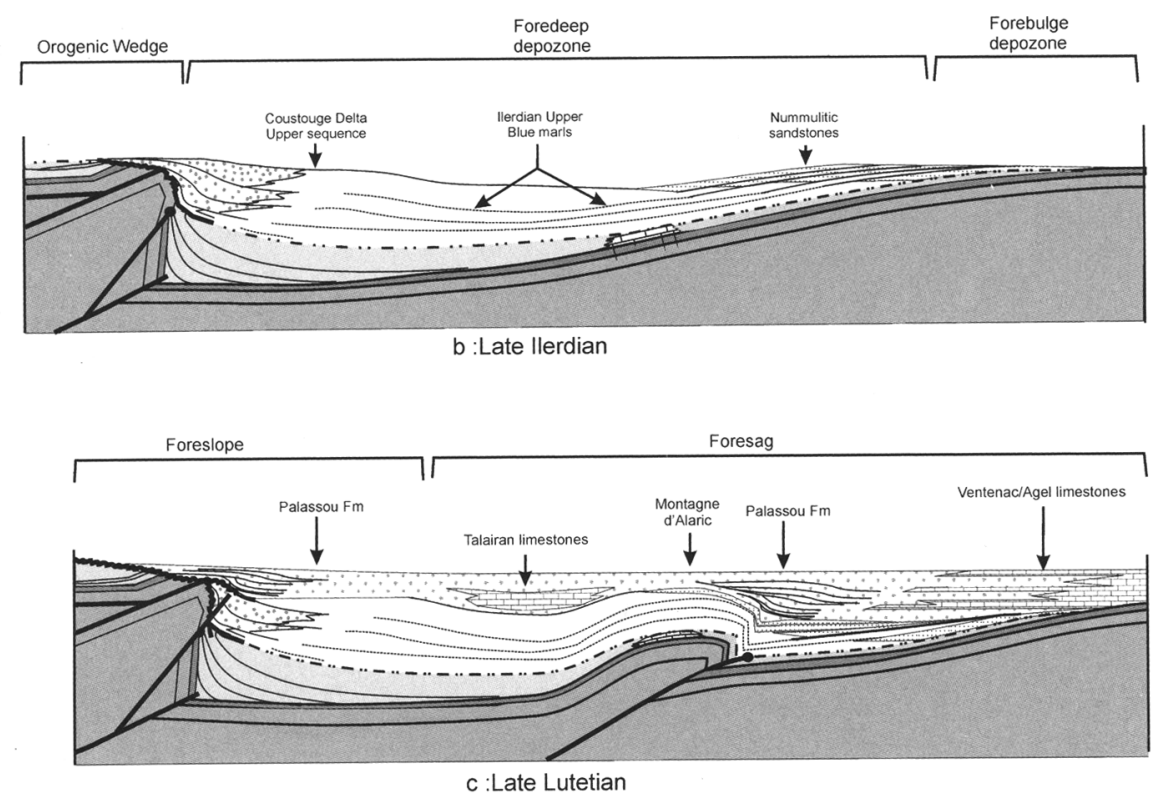

Fig. 10. Schematic evolution of the Eocene basin. No vertical scale. (a) Early to Middle Ilerdian. Lower Blue Marls deposited as a result of the propagation of the lower (northernmost) branch of the Mouthoumet frontal fault-propagation fold. The forebulge is located near the future Alaric Anticline. The backbulge depozone corresponds with the Minervois inner platform and drains northerly sourced clastic deltas. (b) Middle to Late Ilerdian. Upper Blue Marls deposited as a result of the propagation of an upper branch of the Mouthoumet frontal fault-propagation fold. The forebulge migrates on to the Montagne Noire. Northerly sourced clastic deltas feed the foredeep depozone (Oyster and Nummulitic sandstones. (c) Latest Ilerdian to Bartonian. Palassou Formation deposited during ongoing shortening and coeval erosional uplift. Growth structures form as a result of propagation of the Mouthoumet and Alaric frontal thrusts. Lacustrine limestones fill growth synclines. Upwards shallowing of bed dip and dying out of growth structures are attributed to decreasing shortening during ongoing erosional uplift (see text).

forelimbs, demonstrate syndepositional growth of the folds. Deeper erosion of the growth folds towards the south and the northwards-decreasing maturity of the deposits indicate basinward propagation of the thrusts. Syntectonic deposition continuing in the south shows that the rear thrust and related sub-basin incorporated into the wedge remained active, which characterizes the wedge-top depozone (DeCelles \& Giles
1996). This and the coeval northwards migration of the platform in the northern area (Fig. 3) demonstrates craton-ward propagation of the entire basin during Middle Cenomanian to Turonian times. The marine deposits onlapping the southern side of the emerged Mouthoumet high and the thin lagoonal-brackish deposits onlapping its northern side enable us to interpret this high as the forebulge. The Cenomanian- 
Turonian depositional system thus appears as an underfilled foreland basin system (DeCelles and Giles 1996) including:

(1) slope and base-of-slope facies in a turbiditic environment related to a northwards propagating thrust-and-fold wedge (wedgetop and proximal foredeep depozones);

(2) hemipelagites (distal foredeep) and platfom retrogradational deposits onlapping an emerged Palaeozoic forebulge (forebulge depozone); and

(3) to lagoonal-brackish sediment representing the backbulge depozone.

During Coniacian and Early to Middle Santonian times, the 'catastrophic' deposits interfering with the normal sedimentation were derived from the southern limbs of the more northerly Belvianes and Cucugnan Synclines, as shown by detritus of Late Albian age originating from the reworked southern limb of the fold (Fig. 3). The ongoing retrogradational evolution of the northern deposits bears evidence of coeval northwards migration of the platform. The two northern retrogradational sequences separated by an erosional contact are likely to be a result of the propagation of two branches of the Belvianes fault-propagation fold (see Déramond et al. 1993).

Northwards migration of the platform and wedge-front continued during Middle to Late Santonian times. The depocentre filled by the Pla de Sagne and Sougraigne marls must be related to the development of a more northerly faultpropagation fold (locally known as the Bezu Anticline) which was then transported over the catastrophic and other wedge-front deposits to form the North Pyrenean Frontal Thrust (Figs 1 b \& 2). Moreover, the northwards-transported Peyrepertuse megaturbidite indicates that a tectonically unstable carbonate platform was forming at this time on the wedge front.

Overall, the Middle Cenomanian to Late Santonian retrogradational evolution appears to have been a result of wedge-front advance with forward (in-sequence) propagation of thrusts and related sub-basins during increased regional subsidence (Fig. 3). This propagation may have lasted at most $c .10 \pm 3$ or $12 \pm 1 \mathrm{Ma}$, depending on whether Odin's (1994) or Gradstein et al.'s (1994) time scale is used. The average deposition rate as inferred from the Coniacian to late Santonian deposits ( $800 \mathrm{~m}$ total thickness) was thus c. 0.13 to $0.16 \mathrm{~mm} /$ year, which is close to that observed in most of the underfilled foreland basins $(0.1$ to $0.2 \mathrm{~mm} /$ year; Cross 1986; Homewood et al. 1986; Sinclair 1997). Three tectonically controlled sequences were deposited during that time ( 5 to 6 $\mathrm{Ma}$ ), and the propagation of individual thrusts may be inferred to have lasted 1.5 to $2 \mathrm{Ma}$. The Middle Cenomanian to Turonian sequence was more long-lived (c.5-7 Ma); however, the outcrops still preserved show that at least two sub-basins formed successively during this time and that two others, now removed by subsequent tectonics and erosion, may have been associated with the two fault-propagation folds found between the Axat and Belvianes Synclines (Fig. 2). The duration of the development of each new sub-basin would be thus $c .1 .2$ to $2.3 \mathrm{Ma}$, that is of the same order of magnitude as during the Coniacian and Santonian.

Average wedge advance rate and average strain rate estimated using these values and the balanced cross-section, are thus 1.9 to 2.25 $\mathrm{mm} /$ year and c. 1.3 to $1.6 \times 10^{-15} \mathrm{~s}^{-1}$, respectively, which is consistent with the values usually found in active orogens.

Since the propagating thrust-related fold were slightly oblique en échelon folds (WNW-ESEtrending $F_{1} / F_{2}$ folds), it should be inferred that basin propagation and thrusting occurred as a result of normal shortening combined with a minor component of left-lateral strike-slip shearing ('transpression').

Latest Santonian to Paleocene. Since the latest Santonian, the sedimentation displayed a shallowing-upwards evolution which went on until the Thanetian, that is, during a time-span of c. 29-30 Ma (Gradstein et al. 1994; Odin 1994; Serra-Kiel et al. 1998), and includes the transition from underfilled to overfilled. The persistence of the same evolutionary trend during all this time precludes eustasy as the controlling process. The basal erosional unconformity and the depositional evolution may be interpreted as a result of either out-of-sequence thrusting (e.g. Jordan 1995; Schlunegger et al. 1997a, b), or unloading during tectonic quiescence, causing headward erosion of previous submarine highs (Catuneanu et al. 1997, 2000) and/or more internal emergent relief (Blair and Bilodeau 1988; Heller et al. 1988; Burbank 1992; Heller and Paola 1992; Burbank et al. 1996). Out-ofsequence thrusting might have accommodated the internal deformation required for the advancing tapered wedge (Davis et al. 1983) to be maintained or restored in a critical state as erosion proceeded (Boyer 1995; Horton 1999; Schlunegger 1999). This interpretation might be supported by:

(1) the presence of variously sized olistoliths and longitudinal palaeocurrents in the turbiditic 
deposits (Labastide sandstones) in front of the Bugarach Thrust; and

(2) the occurrence in the 'Vitrollian' conglomerates of Mesozoic metamorphic carbonate clasts related to the reactivation of the Axial Zone and/or Bessède-Salvezines frontal thrusts.

Indeed, out-of-sequence thrusting is opposed by several lines of evidence:

(1) Out-of-sequence thrusting would have been responsible for additional loading and increased regional subsidence. If so, the shallowing-upwards evolution observed during the Latest Santonian and Early Campanian would have required the sedimentation rate to be higher than the subsidence rate. This could have occurred only if the basin were mainly fed by the orogen (see, for example, Jordan 1995; Sinclair 1997), which is not the case for the studied basin mainly fed from the northern craton at this time.

(2) Shallowing upwards, together with out-ofsequence thrusting, would have implied backward migration of the entire foredeep and of the loading point, which is inconsistent with the increase in regional shortening that out-of-sequence thrusting should have caused.

(3) The clasts in the conglomerates were issued from multiple point sources in the entire North Pyrenean Zone, and not only from the Mesozoic metamorphic zone, which indicates that no particular relief fed the dispersal system.

(4) Erosion was insufficient to reach the Palaeozoic core of the southern fold-propagation folds (Bessède, Salvezines and Agly massifs) which however, had previously been eroded during Cenomanian and Turonian times, which is inconsistent with the reactivation of the thrusts.

Headward erosion of pre-existing tectonic relief as a result of unloading is therefore more plausible. In the south of the studied area, the sequential evolution and the sources of olistoliths and clasts indicate that headward erosion attained, first submarine reliefs with "passive infilling of the sub-basin (latest Santonian to Early Campanian Labastide sandstones), then the emergent northern North Pyrenean Zone (Late Campanian to Earliest Paleocene 'BegudoRognacian' facies), and finally the southernmost Mesozoic metamorphic zone (early Paleocene 'Vitrollian' facies). Southwards transport of clastics from the Mouthoumet High which continued during Latest Santonian and Early Campanian times ceased after that, and the Palaeozoic material was entirely transported northwards down to the Alaric Depression. The transition from underfilled to overfilled and from longitudinal to transverse drainage thus appear to have been related to a progressive uplift of the whole foreland basin system, and was not provoked by tectonic shortening. Lithospheric mechanisms capable of causing upper plate uplift, such as delamination (Bird 1979; Channel \& Mareschal 1986) or slab-break-off (Davies \& Von Blanckenburg 1995) are rather unlikely here, because of the absence of metamorphism and magmatism in the period and area considered. Traces of these events also cannot be found in the ECORS profiles (ECORS Pyrenees Team 1988). Erosional unloading accompanying tectonic quiescence (Blair and Bilodeau 1988; Heller et al. 1988; Heller and Paola 1992; Burbank 1992; Washbusch et al. 1996; Catuneanu et al. 1997, 1999, 2000) is therefore more likely. Erosional unloading may explain the wide but shallow erosion of the whole North Pyrenean Zone, as evidenced by the absence of Palaeozoic clasts. The northern depression, which is situated rather far beyond the previous underfilled foredeep, could be considered as the 'foresag' (Catuneanu et al. 2000), even though the total thickness of sediments accumulated here $(c .200$ to $300 \mathrm{~m})$ indicates a moderate subsidence rate of 0.015 to $0.02 \mathrm{~mm} /$ year. Uplift is likely to have ceased or considerably decreased at the beginning of Thanetian times as suggested by the predominance of lacustrine/palustrine or lagoonal through marine deposits and of fine- to very fine-grained fluvial deposits. Deposition was probably mainly controlled at this time by eustatic sea-level fluctuations, even though incipient thrusting may have increased the accommodation space locally (Tambareau et al. 1995).

\section{Eocene}

Ilerdian Blue Marls and Oyster Sandstones. Their involvement in growth structures indicates that deposition of both the Lower and Upper Blue Marls was controlled by the development of the Mouthoumet frontal thrust-propagation fold during thrust-wedge advance (Figs 9 \& 10). Ongoing fold growth is revealed by: firstly, the location of the depocentre in the frontal syncline where accomodation space created by regional subsidence was or less reduced or not reduced at all, and secondly, strata wedging which indicates a reduced deposition and deposition rate on to 
the anticline because of reduced accommodation space (Ito et al. 1999). In contrast with the Late Cretaceous sub-basins, the depositional sequences were predominantly coarsening/shallowing upwards, which indicates the increasing contribution of the advancing emerged thrust-wedge (see also DeCelles et al. 1998). However, the fining/deepening-upwards basal parasequence set of the Upper Blue Marls can be interpreted as a result of regional subsidence with no or reduced contribution from the wedge-front during initial fold growth. The duration of the thrust-fault controlled depositional sequences is here c.1-1.2 $\mathrm{Ma}$, which is of the same order of magnitude as the higher order sequences identified in the Late Cretaceous.

The Lower Blue Marls were deposited during the propagation of a lower branch of the Mouthoumet frontal thrust, as shown by the basal growth onlap sealing a thrust fault which affects the pre-growth strata (Figs 6, 9a \& 10a). The Talairan sub-basin of that period is likely to represent the foredeep (sensu DeCelles \& Giles 1996). It is thus tempting to interpret the inner platform as the backbulge depozone. In this case, the outer boundary of the platform, which acted as a barrier for the northerly detrital material and on top of which are observed Solenomeris reefs, could be interpreted as the forebulge (Figs $9 \mathrm{~b} \& 10 \mathrm{a})$. The presence of clasts and slipped blocks derived from this northern platform south of the shelf-break bears evidence of the instability of the slope, which may characterize the forebulge depozone. This interpretation may be opposed by the growth of the reefs (Plaziat \& Perrin 1991) and the absence of a basal unconformity (Crampton \& Allen 1995). However, since a long-term eustatic sea-level rise is signalled from 59 to $52 \mathrm{Ma}$, (Haq et al. 1987; Hardenbol et al. 1998) and forebulge uprise is rather slow (Beaumont et al. 1993), it should reasonably be envisaged that relative sea-level increased as a result of eustasy, while the forebulge rose - thus explaining reef growth and lack of subaerial erosion.

The Upper Blue Marls and overlying Oyster Sandstones are interpreted to be deposited in association with the propagation of an upper/ younger thrust branch of the Mouthoumet frontal thrust locally cutting the Lower Blue Marls and sealed by the basal growth onlap (Figs $6 \& 10 \mathrm{~b}$ ). A renewed and upwards-increasing contribution from the orogen was responsible for younger deltas prograding craton-ward such that the deltaic system finally covered the entire basin, as shown by the presence of the Oyster Sandstones all above the Upper Blue Marls, and of a Gilbert delta in the south (Figs 9c \& 10b). The
Upper Blue Marls overlapped the former shelfbreak and invaded most of the former platform at the same time, indicating coeval northwards migration of the forebulge (Fig. 10b). Overall, the Blue Marls can be interpreted as having been deposited in a widening flexural basin. Wedge advance being less than basin widening, orogenic loading necessarily resulted from thrust stacking to the rear of the basin, which probably corresponds with the development of the Mouthoumet Duplex as also shown by the absence of detritus originating from the North Pyrenean or the southern sub-Pyrenean zones at this time.

The Palassou Formation. The growth stratal depositional patterns at the contact of the Mouthoumet and Alaric anticlines (Figs 6,7 \& 8) as well as the presence of perennial lacustrine/ palustrine depressions in the growth synclines (Talairan and northern Alaric) indicate that deposition of the Palassou Formation was controlled by the propagation of the Mouthoumet and Alaric frontal thrusts (Fig. 10c). The absence of higher sedimentary discharges and debris flows and the presence of multiple channels crossing the growth fold front reveal, however, that these folds played a limited role in the production of sediment and were bypassed by alluvial fans derived from the orogen beyond the Mouthoumet Front. Moreover, the shallow slope depositional environment and the ubiquity of transverse north-south palaeocurrents show that the growing folds in the foreland basin have not significantly disturbed the drainage pattern, which indicates that erosion exceeded tectonic uplift (Burbank et al. 1996). According to Boyer (1995), erosion during wedge advance leads to isostatic adjustments that decrease the dip of the basement, and restoration of the critical taper (sensu Davis et al. 1983) requires thickening of the wedge. Therefore, the decrease in amplitude of the Mouthoumet and Alaric anticlines while the detrital deposits coarsened upwards indicates either internal deformation localizing in the inner orogen as a result of erosion during ongoing thrust-wedge advance, or progressive cessation of the wedge advance coupled with ongoing erosional unloading/uplift. Increasing internal deformation is consistent with decreasing accretion of frontal thrust sheets and limited thrust advance, because deformation absorbs most of the displacement (Boyer 1995). The presence of clasts of North Pyrenean Lower Cretaceous carbonates and sub-Pyrenean Upper Cretaceous sandstones at the basal part of this formation suggests that the Bugarach and other $\mathrm{F}_{3}$ fold and thrusts of the southern subPyrenean/northern North Pyrenean zones 
effectively propagated at this time. However, the absence of clasts derived from the southern basement (e.g. migmatites, granulites or even granites) in the Late Ilerdian to Early Bartonian conglomerates indicates no significant reactivation of the thrusts in the more internal orogen. Again, the accumulation of more than $1000 \mathrm{~m}$ of sediment in the terminal topographic depression between the latest Ilerdian and the Late Bartonian (subsidence rate of c. $0.09 \mathrm{~mm} / \mathrm{year}$ ), suggests that this depression could be the 'foresag' resulting from the flexural uplift of the unloaded orogen (Beaumont et al. 1993; Washbusch et al. 1996; Catuneanu 1997, 2000). Although basement underthrusting in the inner pro-wedge (blind basement duplex?) cannot be ruled out, pure erosional unloading of the inner orogen twinned with sedimentary loading of the outer foreland basin may have been significant at the end of the deposition of the Palassou Formation studied here. The presence of deepbasement clasts in upper units of the Palassou Formation cropping out west of the study area (Crochet 1991) and the apatite fission-tracks ages of exhumation of the Agly Massif (c.47 to 40 Ma) and Axial Zone (c.35 to $26 \mathrm{Ma}$ ) (Morris et al. 1998) strongly suggest, however, that out-ofsequence thrusting and wedge advance occurred during late Eocene-early Oligocene times.

\section{Discussion and conclusion: tracing tectonic events using sedimentary markers}

The present sedimentological-tectonic study provides new insights into the modes of thrustwedge advance and basin propagation, the transition from underfilled to overfilled during loading/unloading cycles, and the integration of the basins in the tectonic history of the range.

\section{Thrust-wedge advance and foreland basin propagation}

The Late Cretaceous basin system can be shown to have formed as a result of the progressive integration into the wedge-top depozone (DeCelles \& Giles 1996) of individual sub-basins during forward propagation of thrust fault-propagation folds. Sedimentological evidence includes:

(1) reworking of the forelimbs of wedge-front fold-propagation folds, shown by "catastrophic' deposits interdigitated with the 'normal' deposits derived from the craton;

(2) deepening-upwards stacking patterns in the fold-controlled sub-basins, resulting from the coeval migration of wedge-front and platform;
(3) overall deepening-upward stacking pattern indicating increased subsidence during thrustwedge advance and craton-wards migration of the entire basin.

The depositional sequences controlled by the development of the Coniacian to Late Santonian sub-basins are well dated from fossil evidence (Bilotte 1992), and do not coincide with the 'global eustatic' sequences established by Hardenbol et al. (1998), even though using the same time-scale (Gradstein et al. 1994).

The Eocene marine basin propagated as a result of widening of a single foredeep with forebulge migration. Sedimentary evidence is borne out by:

(1) the presence of a well-characterized depocentre located in front of a basement duplex;

(2) the individualization of two deepeningupwards depositional sequences;

(3) the presence of growth stratal structures in front and on top of the wedge with a major growth onlap sealing a thrust fault branch at the base of either sequence;

(4) reworking of the forelimb of the frontal fold in both sequences and of the forebulge in the lower sequence.

The fact that craton-ward migration of the platform and forebulge largely exceeded the migration of the wedge-front indicates that there was limited wedge advance coupled with increasing regional flexural subsidence and orogenic loading, probably related to the development of the Mouthoumet basement duplex. Thus it can be stated that local depositional patterns were controlled by the propagation of the frontal fault-propagation fold of a developing basement duplex, which was responsible for an increase in regional subsidence.

The Eocene continental deposits infilled two synchronous fault-propagation-controlled subbasins superimposed on the Eocene marine basin. The most conclusive sedimentological studies are here analyses of facies and architectural elements (according to Miall 1996), palaeocurrents and provenances. Coupled with the analysis of growth stratal patterns, these studies show that the folds, although synsedimentary, did not provide a large amount of sediment and were bypassed by shallow-slope alluvial fans derived from enhanced erosion of the inner orogen during ongoing and then decreasing thrust-wedge advance.

If we consider now the architecture of the depositional sequences with respect to wedge advance, differing indications have been given by 
the underfilled marine basins studied herein. In the Late Cretaceous basin, upwards-fining/ deepening indicates that the subsidence rate was higher than the deposition rate (Catuneanu et al. 1997, 2000), which is likely to occur where the clastic supply is predominantly sourced on the craton ('normal sedimentation'). Apart from the basal coarse breccias of the Middle Cenomanian to Turonian basin, reworking of the forelimbs of the wedge-front folds, although qualitatively important, has provided relatively small amounts of material. This is believed to characterize a submarine wedge with little disruption of the fold limbs, i.e. prevailing ductile flexural folding, during in-sequence thrust propagation. In the Eocene basin, upwards shallowing of the depositional sequences is attributed to increasing erosion of the emerged wedge during overstep propagation of thrust fault branches, which reduced accommodation space despite increasing subsidence. Tectonic quiescence or initial fold growth (low-amplitude stage) during ongoing subsidence is, however, recorded in the foredeep by upwards fining/deepening at the base of the Upper Blue Marls. Fold growth-induced uplift is accommodated by strata wedging with no change in the sequence architecture, which differs from Ito et al.'s (1999) observations in the highest order sequences. This difference may be explained by the limited amplitude of eustatic fluctuations compared with tectonic subsidence and uplift for the time-scale and tectonic context considered here.

\section{Loading/unloading cycles and the transition from underfilled to overfilled}

In the Late Cretaceous-Paleocene basin system, the transition from underfilled to overfilled is interpreted as the change from regional contraction to tectonic quiescence and unloading uplift. This is recorded by the overall deepeningupwards stacking pattern indicating increasing subsidence during thrust-wedge advance, succeeded by a shallowing-upwards stacking pattern indicating progressive 'passive' filling of the basin with an increasing contribution of the emerging orogen and orogen-ward progradation of the platform, and then by fluvial sedimentation. A provenance study coupled with the tectonic study, appear, however, to be a necessary prerequisite for establishing that deposits derived that the deposits issued from the inner orogen were not produced by out-of-sequence thrusting.

During Eocene times, increased erosion of the inner orogen at the origin of the transition from underfilled to overfilled is shown by overall upwards coarsening, progressive decrease in amplitude of the synsedimentary folds in the outer basin, lack of control of drainage by these synsedimentary folds, and origin of the clasts. This can be interpreted to have been a result of erosional unloading coupled with either:

(1) internal deformation restoring the taper angle of the advancing wedge (Boyer 1995) as suggested by synsedimentary folding, or

(2) flexural uplift after cessation of the advance of the wedge, as suggested by the creation of a 'foresag' in the distal part of the basin and the absence of basement clasts which would be produced by out-of-sequence thrusting in the inner orogen, or, more probably,

(3) a combination of events (1) and (2).

\section{Place of the foreland basin in the history of the range}

The above results show that during Late Cretaceous to Paleocene times, the inferred loading and unloading events are clearly separated - the 'passive' phase of the cycle (erosion and isostatic rebound) being three times as long (c.29-30 Ma) as the 'active' phase (tectonic shortening, c.10-12 Ma). Although lasting a relatively short time in the history of the Pyrenean range, Late Cretaceous tectonic shortening thus appears to have been much longer-lived than previously thought on the basis of pure tectonic studies. The deformation rate inferred from balanced sections $\left(c .10^{-15} \mathrm{~s}^{-1}\right)$ is however consistent with those usually observed during lithospheric deformation. On the other hand, the present study is in agreement with those of the previous tectonic studies: stating that the shortening at the origin of the Late Cretaceous folds and thrusts was a result of pure contraction normal to the range, combined with minor left-lateral strike-slip shearing parallel to the North Pyrenean Fault Zone.

The Eocene basins record a new tectonic pulse marked by the propagation of east-west folds and thrusts in a pure compressional context, which lasted at most $c .15 \mathrm{Ma}$ (late Early Ilerdian to Early Bartonian). The tectonic history inferred from the study of the sedimentary infill appears much more complex than previously envisaged, involving in-sequence (Early to Late Ilerdian), out-of-sequence (latest Ilerdian) and synchronous (Latest Ilerdian to Early Bartonian) thrusting.

We thank P. Baby, P. Souquet, Y. Tambareau, and J. Villatte for providing us with unpublished data and stimulating discussions during the completion of this 
work. Midland Valley Inc. is acknowledged for technical support. The manuscript also benefited from constructive reviews by $\mathrm{F}$. Mouthereau and $\mathrm{T}$. McCann.

\section{References}

Arthaud, F., Burg, J. P. \& Matte, P. 1976. L'évolution structurale hercynienne du massif de Mouthoumet (Sud de la France). Bulletin de la Société Géologique de France, 7, XVIII(4), 967-972.

Baby, P., Crouzet, G., Specht, M., Deramond, J., Bilotte, M. \& Debroas, E. J. 1988. Rôle des paléostructures anté albo-cénomaniennes dans la géométrie des chevauchements frontaux nordpyrénéens. Comptes Rendus de l'Académie des Sciences, Paris, 306(II), 307--313.

BEAUMONT, C. 1981. Foreland basins. Geophysical Journal of the Royal Astronomical Society, 137, 291-329.

Beaumont, C., Quinlan, G. M. \& Stockmal, G. S. 1993. The evolution of the Western Interior basin: causes, consequences and unsolved problems. In: CALDWELL, W. G. E. \& KAUFFMAN, E. G., (eds), Evolution of the Western Interior Basin. Geological Association of Canada, Special Paper, 39, 97-117.

Beaumont, C., Muñoz, J. A., Hamilton, J. \& FULLSACK, P. 2000. Factors controlling the Alpine evolution of the Central Pyrenees inferred from a comparison of observations and geodynamical models. Journal of Geophysical Research, 105(Bi4), 8121-8145.

Berger, G. M. \& REY, J. 1990. Ilerdian. In: BERGER, G. M. \& Boyer, Rey, J., Feuille de LézignanCorbières, Carte Géologique de la France à 1/50000, no. 1038, BRGM, Orleans, 70 pp.

Berger, G. M., Boyer, F., Debat, P., Demange, M., Issard, H., Marchal, J. P., Freytet, P. \& Mazeas, H. 1993. Feuille de Carcassonne, Carte Géologique de la France à 1/5000, $n^{\circ} 1037$, BRGM, Orleans, $78 \mathrm{pp}$.

Berger, G. M., Alabouvette, B., Bessiere, G., Bilotte, M., Crochet, B., Dubar, M., Marchal, J. P., Tambareau, Y., Villatte, J. \& Viallard, P. 1997. Feuille de Tuchan, Carte Ggéologique de la France à $1 / 5000$, no. 1078 , BRGM, 113 pp.

Bessiere, G. 1987. Modèle d'évolution polyorogénique d'un massif hercynien: le Massif de Mouthournet (Pyrénées Orientales). Thesis, Université Toulouse III, $317 \mathrm{pp}$.

Bessiere, G., Bilotte, M., Crochet, B., Peybernes, B., Tambareau, Y. \& Vilatte, J. 1989. Feuille de Quillan, Carte géologique de la France à 1/50 00, no. 1077, BRGM, 98 pp.

Bilotte, M. 1985. Le Crétacé supérieur des plateformes Est-pyrénéennes, Strata, 2(5), p. 438.

BilotTe, M. 1992. Enregistrement sédimentaire et datation du passage de la marge stable à la marge convergente durant le Sénonien dans la zone souspyrénéenne orientale (Corbières, France). Comptes Rendus de l'Académie des Sciences Paris, 315. $77-82$.

Bilotte, M., Fondecave, M.-J., Peybernes, B., Souquet, P. \& Wallez J.-P. 1973. Distinction de
l'Albien et du Crétacé supérieur dans le synclinorium d'Axat (Pyrénées). Comptes Rendus Sommaires de la Société Géologique de France, 5-6, 119-121.

BIRD, P. 1979. Continental delamination and the Colorado Plateau. Journal of Geophysical Research, 84, 7561-7571.

Blair, T. C. \& Bilodeau, W. L. 1988. Development of tectonic cyclothems in rift, pull-apart and foreland basins: sedimentary response to episodic tectonism. Geology, 16, 517-520.

BOYER, S. E. 1995. Sedimentary basin taper as a factor controlling the geometry and advance of thrust belts. American Journal of Science, 295, 1220-1254.

Brusset, S., Deramond, J. \& Souquet, P. 1997. Evolution tectono-sédimentaire des bassins flexuraux à taux de sédimentation réduite: exemple du basin flysch de St Jean-de-Luz (Pyrénées Atlantiques, France) au Crétacé supérieur. Comptes Rendus de l'Académie des Sciences, Paris, IIa, 325, 265-171.

Burbank, D. W. 1992. Causes of the recent Himalayan uplift deduced from deposited patterns in the Ganges basin. Nature, 357, 680-682.

Burbank, D. W., Meigs, A. \& Brozovics, N. 1996. Interactions of growing folds and coeval depositional systems. Basin Research, 8, 199-223.

Burbank, D. W., Puigdefabregas, C. \& MuÑoz, J. A. 1992. The chronology of the Eocene tectonic and stratigraphic development of the eastern Pyrenean foreland basin, Northeast Spain. Geological Society of America Bulletin, 104, 1101-1124.

Burkhard, M. \& Sommaruga, M. 1998. Evolution of the western Swiss Molasse basin: structural relations with the Alps and the Jura Belt. In: Mascle, A., Puigdefabregas, C., Luterbacher, H. P. \& Fernandez, M. (eds) Cenozoic Foreland Basins of Western Europe, Special Publication of the Geological Society, 134, 279-298.

Carter, R. M., Abbot, A. T., Fulthorpe, C. S. Haywick, D. W. \& Henderson R. A. 1991. Application of global sea-level and sequencestratigraphic models in Southern Hemisphere Neogene strata from New Zealand. In: MACDONALD, D. I. M., (ed.) Sedimentation, Tectonics and Eustasy. International Association of Sedimentologists Special Publication, 12, 41-65.

Catuneanu, O., Miall, A. D. \& Sweet, A. R. 1997. Reciprocal architecture of Bearpaw T-R sequences, Uppermost Cretaceous, Western Canada. Sedimentary Basin, 45(1), 75-94.

Catuneanu, O., Sweet, A. R. \& Miall, A. D. 2000. Reciprocal stratigraphy of the CampanianPaleocene, Western Interior of North America. Sedimentary Geology, 134, 235-255.

Channel, J. E. T. \& Mareschal, J. C. 1986. Delamination and asymmetric lithospheric thickening in the development of the Tyrrhenian Rift. In: Coward, M. (ed.) Alpine tectonics, Special Publication of the Geological Society, 45, 285-302.

Choukroune, P. 1976. Structure et évolution tectonique de la zone Nord-Pyrénéenne. Analyse de la déformation dans une portion de chaîne à schistosité sub-verticale. Mémoire de la Société Géologique de France, 55(217). 
Choukroune, P. \& Mattaler, M. 1978. Tectonique des plaques et Pyrénées: sur le fonctionnement de la faille transformante nord-pyrénéenne: comparaison avec des modèles actuels. Bulletin de la Société Géologique de France, 20, 689-700.

Choukroune, P. \& Meurisse, M. 1970. Phases de déformations superposées dans le Mésozoïque de la zone nord-pyrénéenne sur la transversale du massif de Salvezines (Aude). Comptes Rendus de l'Académie des Sciences, Paris, D, 270, 14-17.

Christophoul, F., Baby, P. \& Davila, C. 2002. Stratigraphic responses to a major tectonic event in a foreland basin: the Ecuadorian Oriente Basin from Eocene to Oligocene times. Tectonophysics, 345, 281-298.

Clifton, H. E., Hunter, R. E. \& Gardner, J. V. 1988. Analysis of eustatic, tectonic and sedimentologic influences on transgressive and regressive cycles in the upper Cenozoic Merced Formation, California. In: KLEINSPEHN, K. L. \& PAOlA, C. (eds) New Perspectives in Basin Analysis, SpringerVerlag, New York, 109-128.

Crampton, S. L. \& Allen, P. A. 1995. Recognition of forebulge unconformities associated with early stage foreland basin development: example from the North Alpine Foreland Basin. AAPG Bulletin, 79, 1495-1514.

Crochet, B. 1991. Molasses syntectoniques du versant nord des Pyrénées: la série de Palassou. Documents du BRGM, 199, 387 pp.

Cross, T. A. 1986. Tectonic control of foreland basin subsidence and Laramide style deformation, western United States. In: Allen, P. A. \& HoMewood, P. (eds.) Foreland Basins. International Association of Sedimentologists Special Publication, 8, 15-39.

Davies, J. H. \& Von Blanckenburg, F. 1995. Slab Breakoff: a model of lithosphere detachment and its test in magmatism and deformation of collisional orogens. Earth and Planetary Science Letters, 129, 85-102.

Davis, D. M., Suppe, J. \& Dahlen, F. A. 1983. Mechanics of fold-and-thrust belts and accretionary wedges. Journal of Geophysical Research, 88, 1153-1172.

Decelles, P. G. \& Giles, K. A. 1996. Foreland basin systems, Basin Research, 8, 105-123.

Decelles, P. G., Gehrels, G. E., Quade J. \& OJha, T. P. 1998. Eocene-Early Miocene basin development and the history of Himalayan thrusting, western and central Nepal. Tectonics, 17(5), 741-765.

Déramond, J., Souquet, P., Fondecave-Wallez, M. J. \& SPECHT, M. 1993. Relationships between thrust tectonics and sequence stratigraphy surfaces in foredeeps: model and examples from the Pyrenees (Cretaceous-Eocene, France, Spain). Geological Society of London Special Publication, 71, 193-219.

DoncieuX, L. 1912. Révision de la faune lacustre de l'Eocène moyen des Corbières Septentrionales. Bulletin de la Société des Etudes Scientifiques de l'Aude, 13, 25-50.

Ecors Pyrenees Team 1988. The ECORS deep reflection survey across the Pyrenees. Nature, 331, $508-511$.
EInSEle, G. 1992. Subsidence, In: EInsele, G. (ed.), Sedimentary Basins: Evolution, Facies and Sediments Budget, Springer-Verlag, pp. 313-344.

Ford, M., Williams, E. A., Artoni, A., Vergès, J. \& HARDY, S. 1997. Progressive evolution of a faultrelated fold pair from growth strata geometries, Sant Llorenç de Morunys, SE Pyrenees. Journal of Structural Geology, 19(3-4), 413-441.

FreyteT, P. 1970. Les dépôts continentaux du Crétacé supérieur et des couches de passage à l'Eocène en Languedoc. Thesis, Paris-Sud, 530 pp.

GÉlard, J. P. 1969. Structure de la région située entre Quillan et le Pech de Bugarach. Bulletin de la Société Géologique de France, 7(11), 345-353.

Gilbert, G. K. 1885. Topographic features of lakes shores. Annual Report of the US Geological Survey, 5, 75-123.

Gradstein, F. M., Agterberg, F. P., OgG, J. G., Hardenbol, J. G., Van Veen, P., Thierry, J. \& HuANG, Z. 1994. A Mesozoic time scale. Journal of Geophysical Research, 99(B12), 24051-24074.

HaQ, B. U., HARDEnBol, J. \& VAIL, P. R. 1987. Chronology of fluctuating sea levels since the Triassic (250 million years ago to present). Science, 235, 1156-1167.

Hardenbol, J., Thierry, J., Farley, M. B., Jacquin, T., De Graciansky, P. C. \& Vail, P. R. 1998. Mesozoic and Cenozoic sequence stratigraphic framework of European basins. In: DE GRACIANSKY, P. C., JacQuin, T. \& VAIL, P. R. (eds) Mesozoic and Cenozoic Sequence Stratigraphy of European Basins. SEPM Special Publication, 60.

Heller, P. L. \& PaOla, C. 1992. The large scale dynamics of grain-size variation in alluvial basins, 2: application to syntectonic conglomerates. Basin Research, 4, 91-102.

Heller, P. L., Angevine, C. L. T., Winslow, N. S. \& PAOLA, C. 1988. Two-phase stratigraphic model of foreland-basin sequences. Geology, 16, 501-504.

Homewood, P., Allen, P. A. \& Williams, G. D. 1986. Dynamics of the Molasse basin of western Switzerland. In: AlleN, P. A. \& Homewood, P. (eds) Foreland Basins. International Association of Sedimentologists Special Publication, 8, 199-217.

Horton, B. K. 1999. Erosional control on the geometry and kinematics of thrust belt development in the central Andes. Tectonics, 18, 1292-1304.

Horton, B. \& Decelles, P. G. 2001. Modern and ancient fluvial megafans in the foreland basin system of the central Andes, southern Bolivia: implications for drainage network evolution in fold-thrust belts. Basin Research, 13, 43-46.

Ito, M., Nishikawa, T. \& Sugimoto, H. 1999. Tectonic control of high-frequency depositional sequences with durations shorter than Milankovitch cyclicity: an example from the Pleistocene paleoTokyo Bay, Japan. Geology, 27(8), 763-766.

JoRDAN, T. E. 1995. Retroarc foreland and related basins. In: BusBy, C. J. \& Ingersoll, R. V. (eds) Tectonics of Sedimentary Basins. Blackwell Science, Oxford, 331-362.

Jordan, T. E., Fleming, P. B. \& Beer, J. A. 1988. Dating thrust-fault activity by use of foreland-basin strata. In: KLeINSPeHN, K. L. \& PAOLA, C. (eds) 
New Perspective in Basin Analysis. Springer-Verlag, Berlin, 307-330.

LEBLANC, D. \& VAUdin, J. L. 1984. Les déformations du Mésozoïque de la zone nord-pyrénéenne à l'est de l'Aude. Bulletin du Bureau de Recherches Géologiques et Minières, Géologie de la France, $\mathbf{4}$, $57-68$.

Magné, J. \& Mattauer, M. 1968. Sur la présence du Cénomanien-Turonien dans le série schisteuse de la couverture nord de la zone axiale des Pyrénées au Sud de Quillan (Aude). Bulletin du Bureau de Recherches Géologiques et Minières, Géologie de la France, 21(3), 39-43.

Massieux, M. 1973. Micropaléontologie stratigraphique de l'Eocène des Corbières Orientales (Aude). Cahiers de Paléontologie, 146 pp.

Mattauer, M. \& Proust, F. 1965. Sur la présence et la nature de deux importantes phases tectoniques dans les terrains secondaires des Pyrénées orientales. Comptes Rendus Sommaires de la Société Géologique de France, 5, 132-133.

Miall, A. D. 1996. The Geology of Fluvial Deposits, Sedimentary Facies, Basin Analysis and Petroleum Geology. Springer, Berlin, Heidelberg and New York, $582 \mathrm{pp}$.

Morris, R. G., Sinclair, H. D. \& Yelland, A. J. 1998. Exhumation of the Pyrenean orogen: implications for sediment discharge. Basin Research, 10, 69-85.

Muñoz, J. A. 1992. Evolution of a continental collision belt: Ecors Pyrenees crustal balanced cross section. In: MCCLAY, K. R. (ed.) Thrust Tectonics. Chapman \& Hall, London, 235-246.

Nemec, W. \& Steel, R. J. 1988. Fan deltas: Sedimentology and Tectonic Settings. Blackie, London, $464 \mathrm{pp}$.

NiJMan, W. 1998. Cyclicity and basin axis shift in a piggyback basin: toward modelling of the Eocene Tremp-Ager Basin, South Pyrenees, Spain. In: Mascle, A., Puigdefabregas, C., Luterbacher, H. P. \& Fernandez, M. (eds) Cenozoic Foreland Basins of Western Europe, Special Publication of the Geological Society, 134, 135-162.

Odin, G. S. 1994. Geological time scale. Comptes Rendus de l'Académie des Sciences, Paris, 318, 59-71.

Pautal, L. 1985. Populations fossiles, associations micropaléontologiques et paléoenvironnements des séries deltaïques ilerdiennes des Corbières (Aude, France). Thesis, Université Toulouse III, 288 pp.

Pelissier, P. 1987. Etude sédimentologique des Grès de la Bastide (Santonien Supérieur-Campanien) dans le synclinal sous-pyrénéen St Louis (Hautes Corbières). Thesis, Université Toulouse III, $111 \mathrm{pp}$.

Plaziat, J. C. 1984. Stratigraphie et évolution paléogéographique du domaine pyrénéen de la fin du Crétacé (phase maastrichtienne) à la fin de l'Eocène (phase pyrénéenne). Thesis, Université Paris VI, $1200 \mathrm{pp}$.

Plaziat, J. C. 1987. Ilerdian.. In: Ellenberger, F., Freytet, P., Plaziat, J. C., Bessiere, G., Viallard, P., Berger, G. M. \& Marchal, J. P. (eds) Feuille de Capendu, Carte géologique de la France à $115000, n^{\circ} 1090$, BRGM, Paris, 88 .
Plaziat, J. C. \& Perrin, C. 1991. Multikilometer-sized reefs built by foraminifera (Solenomeris) from the early Eocene of the Pyrenean domain (S France, N Spain)-Paleoecological relations with coral reefs. Palaeogeography Palaeoclimatology Palaeoecology, 96(3-4), 195-231.

Puigdefrabregas, C. \& Souquet, P. 1986. Tectosedimentary cycles and depositional sequences of the Mesozoic and Tertiary from the Pyrenees. Tectonophysics, 129(1-4), 173-203.

Puigdefrabregas, C., Muñoz, J. A. \& Marzo, M. 1986. Thrust belt development in the eastern Pyrenees and related depositional sequences in the southern foreland basin. In: AlleN, P. A. \& Homewood, P. (eds) Foreland Basins, Special Publication of the International Association of Sedimentologists, 8, 229-246.

RAZIN, P. 1989. Evolution tectono-sédimentaire alpine des Pyrénées Basques à l'Ouest de la transformante de Pamplona (Province du Labourd). Thesis, Université Bordeaux 3, 464 pp.

Reading, H. G. \& Collinson, J. D. 1996. Clastic coasts. In: ReAdING, H. G. (ed.) Sedimentary Environments: Processes, Facies and Stratigraphy. Blackwell Science, 3rd edn. 154-230.

REy, J. \& Bousquet, J. P. 1981. Observations préliminaires sur les paléoenvironnements de l'Ilerdien de Coustouge (Aude, France). Geobios, 14(5), 655-659.

Riccr LuCCHI, F. 1986. The Oligocene to Recent foreland basins of the northern Apennines. In: Allen, P. A. \& Homewood, P. (eds) Foreland Basins. Special Publication of the International Association of Sedimentologists, 8, 105-139.

SCHLUNEGGER, F. 1999. Controls of surface erosion on the evolution of the Alps: constraints from the stratigraphies of the adjacent foreland basins. International Journal of Earth Sciences, 88, 285-304.

Schlunegger, F., Matter, A., Burbank, D. W. \& KlAPER, E. M. 1997a. Magnetostratigraphic constraints on relationships between evolution of the central Swiss Molasse basin and Alpine orogenic events. Geological Society of America Bulletin, 109, 225-241.

Schlunegger, F., Matter, A., Burbank D. W., LeU, W., Mange, M. \& MÀtyas, J. 1997b. Sedimentary sequences, seismofacies, and evolution of depositional systems of the Oligo/Miocene Lower Freshwater Molasse Group, Switzerland. Basin Research, 9, 1-26.

SEgUier, J. 1972. Etude stratigraphique du Paléozoïque du Cabardès (versant sud de la Montagne Noire) et de sa couverture Eocène. Thesis, Université Toulouse III, $104 \mathrm{pp}$.

SERRA KIEL, J. et al. 1998. Larger foraminiferal zonation, Tethys ocean, IGCP 286 (Early Paleogene Benthos), IGCP 393 (neritic events at the MiddleUpper Eocene boundary). Bulletin de la Société Géologique de France, 169(2), 281-299.

Serrano, O., Gulllocheau, F. \& Leroy, E. 2001. Évolution du bassin compressif Nord-Pyrénéen au Paléogène (bassin de l'Adour): contraintes stratigraphiques. Comptes Rendus de l'Académie des Sciences, Paris, 332, 37-44. 
Sinclair, H. D. 1992. Turbidite sedimentation during Alpine thrusting: the Taveyannaz Sandstones of eastern Switzerland. Sedimentology, 39, 837-856.

SinCLAIR, H. D. 1993. High resolution stratigraphy and facies differentiation of the shallow marine Annot Sandstones, south-east France. Sedimentology, 40, 955-978.

SinClaiR, H. D. 1997. Tectonostratigraphic model for underfilled peripheral foreland basins: An alpine perspective. Geological Society of America Bulletin, 109(3), 324-346.

SoulA, J.-C. \& BESSIERE, G. 1980. Sinistral horizontal shearing as a dominant process of deformation in the Alpine Pyrenees. Journal of Structural Geology, 2, 69-74.

Soula, J.-C., Lamouroux, C., Viallard, P., Bessiere, G., Debat, P. \& Ferret, B. 1986. The mylonite zones in the Pyrenees and their place in the Alpine tectonic evolution. Tectonophysics, 129. $115-147$.

Souqlet, P., Eschard, R. \& Lods, H. 1987. Facies sequences in large-volume debris-and-turbidity flows deposits from the Pyrenees (Cretaceous; France, Spain). Geomarine Letter, 7, 83-90.

SPECHT, M. 1989. Tectonique de chevauchement le long du profil ECORS Pyrénées: un modèle d'évolution de prisme d'accrétion continental. Thesis, Université de Bretagne Occidentale, Brest, 353 pp.

Stanistreet, I. G. \& McCarthy, T. S. 1993. The Okavongo Fan and the classification of subaerial fan systems. Sedimentary Geology, 58, 115-133.

Suppe, J., Chou, G. T. \& Hook, S. C. 1992. Rates of folding and faulting determined from growth strata. In: MCClAY, K. R. (ed.) Thrust Tectonics. Chapman and Hall, London, 105-121.

Tambareau, Y., Crochet, B., Villatte, J. \& DERAMOND, J. 1995. Evolution tectono-sédimentaire du versant nord des Pyrénées centre-orientales au Paléocène et à l'Eocène inférieur. Bulletin de la Société Géologique de France, 166(4), 375-387.

Vail, P. R., Audemard, F., Bowman, S. A., Eisner, P.
N. \& Perez-Cruz, C. 1991. The stratigraphic signatures of tectonics, eustasy and sedimentology - an overview. In: Einsele, G. \& SeIlacher, A. (eds) Cycles and Events in Stratigraphy. SpringerVerlag, Berlin, 617-659.

Verges, J., Marzo, M., Santaeularia, T., SerraKiel, J., Burbank, D. W., Muñoz, J. A. \& GIMENEZ-MONTSANT. J. 1998. Quantified vertical evolution of the SE Pyrenean foreland Basin. In: Mascle, A., Puigdefabregas, C., Luterbacher, H. P. \& Fernandez, M. (eds) Cenozoic Foreland Basins of Western Europe. Special Publication of the Geological Society, 134, 107-134.

WAllez, J. P. 1974. Stratigraphie et structure de la partie méridionale du pays de Sault (Aude). Thesis, Université Toulouse III, $143 \mathrm{pp}$.

WALLEZ-FondecAVE, M.-J. \& SOUQUeT, P. 1991. Signatures stratigraphiques de l'eustatisme et de la tectonique de chevauchement dans le Crétacé supérieur du versant nord des Pyrénées; exemple de la zone sous-pyrénéenne orientale (Corbières, France). Comptes Rendus de l'Académie des Sciences Paris, 312, 631-637.

Washbusch, P., Catuneanu, O. \& Beaumont, C. 1996. A combined tectonic/surface process model for the formation of reciprocal stratigraphies. EOS - Transactions of the American Geophysical Union, 701

Williams, E. A., Ford, M., Vergés, J. \& Artoni, A. 1998. Alluvial gravel sedimentation in a contractional growth fold setting, Sant Llorenç de morunys, southeastern Pyrenees. In: MASCLE, A., Putgdefabregas, C., Luterbacher, H. P. \& FERnANDEZ, M. (eds) Cenozoic foreland basins of western Europe. Special Publication of the Geological Society, 134, 69-106.

YoshidA, S., Willis, A. \& Miall, A. D. 1996. Tectonic control of nested sequence architecture in the Castelgate Sandstone (Upper Cretaceous), Book Cliffs, Utah. Journal of Sedimentary Research, 66, 737 - 748 . 